\title{
$\begin{array}{lllllllllllllllll}\mathbf{R} & \mathbf{O} & \mathrm{Z} & \mathbf{P} & \mathbf{R} & \mathbf{A} & \mathbf{W} & \mathbf{Y} & \text { I } & \text { A } & \mathbf{R} & \mathbf{T} & \mathbf{Y} & \mathrm{K} & \mathbf{U} & \mathbf{L} & \mathbf{Y}\end{array}$
}

Ks. Wojciech Góralski

Ius Matrimoniale

30 (2019) $\mathrm{nr} 3$

Wydział Prawa Kanonicznego UKSW

DOI:10.21697/im.2019.30.3.01

ORCID: 0000-0001-6548-4120

\section{Uzupełnienie braku upoważnienia do asystowania przy zawieraniu małżeństwa wyrazem ochrony dobra wspólnego}

Treść: Wstęp. 1. Świadek urzędowy zawarcia małżeństwa i charakter jego uprawnienia. 2. Kształtowanie się normy prawnej o uzupełnieniu uprawnienia świadka urzędowego do asystowania przy zawieraniu małżeństwa. 3. Uzupełnienie uprawnienia w sytuacji błędu powszechnego, a także wątpliwości pozytywnej i prawdopodobnej oraz podstawa uzupełnienia. 4. Uzupełnienie uprawnienia w orzecznictwie Roty Rzymskiej. 4.1. Wyrok c. Stankiewicz z 15.12.1992 roku. 4.2. Wyrok c. Pompedda z 14 lutego 1997 roku. 4.3. Wyrok c. Pinto z 5.07.2003. 4.4. Wyrok c. McKay z 27 października 2006 roku. Zakończenie.

\section{Wstęp}

Jakkolwiek małżeństwo powstaje przez zgodę stron (kan. $1057 \$ 1$ $\mathrm{KPK})^{1}$, to jednak do ważności tego związku niezbędne jest zachowanie formy kanonicznej (zwyczajnej lub nadzwyczajnej) ${ }^{2}$; zawarcie małżeństwa jest zatem aktem formalnym³ ${ }^{3}$.

Wprowadzony w 1563 roku przez Dekret Tametsi Soboru Trydenckiego wymóg formy kanonicznej ${ }^{4}$, podtrzymany (wraz z bliższym

1 Por. kan. $1081 \$ 1$ KPK z 1917 r.

2 Kan. $1108 \$ 1-2$ KPK i $1116 \$ 1-2$ KPK.

3 G. DzIERżon, Funkcje formy kanonicznej w kanonistycznym systemie prawa małżeńskiego, Ius Matrimoniale 7 (13) (2002), s. 111.

4 Por. Concilium Tridentinum, Decretum „Tametsi”(11.11.1563), w: G. Alberigo, G. Dosetti, P. Joannou, C. Leonardi, P. Prodi (red). Conciliorum Oecumenicorum Decreta, Bologna 1995, s. 755. 
określeniem jej elementów) przez Dekret Kongregacji Soboru Ne temere z 2 sierpnia 1907 roku $^{5}$ i usankcjonowany przez KPK z 1917 roku $^{6}$, a następnie przez KPK z 1983 roku$^{7}$, stanowi przesłankę konieczną zawarcia małżeństwa.

Wychodząc z założenia, że forma zawarcia małżeństwa została ustanowiona w celu wyeliminowania małżeństw tajnych, ustawodawca (modyfikując kan. 209 KPK z 1917 roku) ${ }^{8}$ stanowi w kan. 144 $\$ 1$ Kodeksu obowiązującego, iż w przypadku błędu powszechnego, faktycznego czy prawnego, a także w przypadku wątpliwości pozytywnej i prawdopodobnej, prawnej lub faktycznej, Kościół uzupełnia władzę rządzenia wykonawczą, zarówno w zakresie zewnętrznym, jak i wewnętrznym. Natomiast kan. 144 \$ 2 KPK z 1983 roku deklaruje, iż ten sam przepis ma zastosowanie do uprawnień, o których mowa w kan. 882, 883, 966 oraz $1111 \$ 1$ KPK. Właśnie ten ostatni kanon, wyżej powołany, reguluje dziedzinę delegowania przez ordynariusza miejsca (kapłanom i diakonom) upoważnienia, także ogólnego, do asystowania przy zawieraniu małżeństw.

Zgodnie z brzmieniem kan. $1111 \$ 1 \mathrm{KPK}$, uzupełnienie upoważnienia nie dotyczy przypadków odnoszących się do braku upoważnienia do asystowania przy zawieraniu małżeństwa, jeśli upoważnienie to otrzymują od biskupa diecezjalnego, w myśl kan. $1112 \$ 1 \mathrm{KPK}$, wierni świeccy. Nie znajduje też zastosowania w sytuacji, w której nupturienci, o których w kan. 1117 KPK, zawierają małżeństwo wobec osób,

5 Decretum „Ne temere” (2.08.1907), ASS 40 (1907), s. 525-530.

6 Kan. 1094 i 1098 KPK.

7 Kan. 1108 \$ 1-2 KPK i $1116 \$ 1-2$ KPK.

8 Papieska Komisja do Interpretacji KPK 26 marca 1952 roku uznała stosowanie normy kan. 209 KPK do uprawnienia asystowania przy zawieraniu małżeństwa. Por. Pontificia Commissio Pro Interpetatione CIC, Responsum diei 26 martiii 1952: An praescriptum can. 209 appliandum sit in casu sacerdotis, qui, delegatione carens, matriminio assistit. R. Affirmative, AAS 44 (1952), s. 497. Już wcześniej przyjmowano to w orzecznictwie rotalnym. Por. DeC. C. WYNEn z 01.02.1937, SRRD 29 (1937), s. 59-60; Dec. C. Jullien z 24.05.1939, SRRD 31 (1939), s. 310-312; DeC. C. WYNEN z 30.07.1941, SRRD 33 (1941), s. 721-722. 
które nie są zdolne do otrzymania uprawnienia do asystowania przy zawieraniu małżeństwa9.

\section{1. Świadek urzędowy zawarcia małżeństwa i charakter jego uprawnienia}

Stosownie do kan. $1108 \$ 1 \mathrm{KPK}$, w sytuacji zwyczajnej małżeństwo powinno być (ad validitatem) zawarte w obecności świadka urzędowego (inaczej kwalifikowanego) oraz dwóch świadków zwykłych (forma zwyczajna). Świadkiem urzędowym, do którego należy pytanie nupturientów o zgodę małżeńską i przyjęcie jej w imieniu Kościoła (kan. $1108 \$ 2 \mathrm{KPK}$ ), jest - w granicach własnego terytorium - ordynariusz miejsca i proboszcz, a także kapłan lub diakon delegowany przez jednego z nich (kan. $1108 \$ 1 \mathrm{KPK}$ ).

Zarówno ordynariusz miejsca, jak i proboszcz, dopóki ważnie sprawują swój urząd, mogą delegować kapłanom i diakonom również ogólne upoważnienie do asystowania przy zawieraniu małżeństw w granicach swojego terytorium (kan. $1111 \$ 1 \mathrm{KPK}$ ); taka delegacja ogólna powinna być udzielona na piśmie (kan. $1111 \$ 2 \mathrm{KPK}$ ). Delegacja specjalna może być udzielona na piśmie albo ustnie, a także równoważnymi znakami zewnętrznymi ${ }^{10}$.

Delegacja, tak ogólna, jak i specjalna, powinna być udzielana wyraźnie, określonej osobie (wskazanej imiennie lub według sprawowanego urzędu); nie uznaje się natomiast delegacji udzielonej „kapłanowi, kóry będzie odprawiał Mszę św.” (chyba że zostanie określony), ani kapłanowi, którego wybiorą nupturienci czy którego wyznaczy przełożony zakonny.

Delegowany na stałe może subdelegować uprawnienie do poszczególnych przypadków, jeżeli zaś ma delegację specjalną, może je subdelegować, gdy otrzymał wyraźną autoryzację od delegującego. Takiej samej autoryzacji delegującego wymaga subdelegowany, by

\footnotetext{
9 J. KRAJCZYŃSKI, Uzupetnienie uprawnienia do asystowania przy zawarciu matżeństwa, Ius Matrimoniale 13 (19) (2008), s. 129.

10 Por. Dec. C. Matttioli z 21.06.1966, SRRD 58 (1966), s. 647.
} 
swoje uprawnienie mógł ponownie subdelegować ${ }^{11}$. Nie wystarcza delegacja milcząca albo domniemana ${ }^{12}$.

Od delegowango wymaga się świadomości udzielonej mu delegacji oraz jej zaakceptowania (przynajmniej implicite) ${ }^{13}$.

W orzecznictwie rotalnym przyjmuje się (przyjmowano tak również pod rządami KPK z 1917 roku), iż upoważnienie do asystowania przy zawieraniu małżeństwa nie jest aktem jurysdykcji sensu stricto ${ }^{14}$. Taki akt uczestniczy w naturze jurysdykcyjnej, ponieważ wyraża się w nim uznanie Kościoła w taki sam sposób, jak obecność notariusza wymaganą do ważności niektórych aktów na forum cywilnym ${ }^{15}$. W konsekwencji, w stosunku do aktu asystowania przy zawieraniu małżeństwa aplikuje się szereg norm dotyczących posiadania i przekazywania władzy jurysdykcyjnej (jej delegowania, subdelegowania), a także ustania czy uzupełnienia ${ }^{16}$.

Uprawnienie do asystowania przy zawieraniu małżeństwa, choć nie jest aktem wykonawczej władzy rządzenia, to jednak niewątpliwie jest aktem jurysdykcyjnym, co sprawia, że odnoszą się doń wszystkie normy prawne dotyczące władzy rządzenia. Można powiedzieć, że wyłączność owego uprawnienia rodzi wymóg delegowania go do ważnego spełniania aktu prawnego, jakim jest asystowanie przy zawieraniu małżeństwa (kan. $1111 \S 2 \mathrm{KPK}$ ).

\footnotetext{
11 Por. kan. 137-138 KPK.

12 Por. M.A. Ortíz, La supplenza di facoltà per assistere al matrimonio e la funzione della forma al servizio dello ,ius connubii”, w: H. Franceschi, M.A. OrTíz (red.) Ius et matrimonium. Temi di diritto matrimoniale e processuale canonico, Roma 2015, s. 52.

13 TAmŻE, s. 52-53; L. Bender, Forma iuridica celebrationis matrimonii. Commentarius in canones 1094-1099, Roma-Parigi-New York-Tournae 1960, s. 106.

14 „Assistentiam matrimonii non esse actum iurisdictionis quidquid dicant auctores, qui saltem iurisdictionoi sensu latissimo et prorsus improprio eam accendere autumant”. DEC. C. GRAZIOLI Z 17.09.1942, SRRD 34 (942), s. 832.

15 Por. Dec. C. Palestro z 19.02.1986, RRD 78 (1986), s. 104.

16 Por. G. Michiels, De potestate ordinaria et delegata, Parisiis-Tornaci-Neo Eboraci 1964, s. 56; DEC. C. STANKIEWICZ z 15.12.1992, RRD 84 (992), s. 664-679.
} 


\section{Kształtowanie się normy prawnej o uzupełnieniu uprawnienia świadka urzędowego do asystowania przy zawieraniu małżeństwa}

Zasada uzupełnienia władzy, mająca swoje korzenie w prawie rzymskim $^{17}$, znana w Dekrecie Gracjana ${ }^{18}$ i w Dekretałach Grzegorza IX ${ }^{19}$, rozwijana w dziełach kanonistów średniowiecznych ${ }^{20}$, znalazła się w KPK z 1917 roku $^{21}$, a następnie w Kodeksie obowiązującym²2.

Po Dekrecie Tametsi Soboru Trydenckiego aplikowano uzupełnienie w materii małżeńskiej niemal zawsze dla rozwiązania przypadków analogicznyh w stosunku do błędu w nominacji tego, kto wykonywał akt jurysdykcji. Tak np. Kościół uzupełniałbrak polegający na tym, że proboszcz został mianowany w sposób wadliwy. Następnie przyjmowało się, iż uzupełnienie zachodzi również w odniesieniu do tego, kto nie miał żadnej nominacji, lecz był uważany za kompetentnego przez wiernych i określany mianem proboszcza „domniemanego”, uznawanego za takiego przez małżonków. Ważnie asystował przy zawieraniu małżeństwa, przynajmniej wtedy, gdy miał jakiś tytuł pozorny

17 D. 33, 10, 3, 5; Por. także P. PAŁKA, Uzupetnienie jurysdykcji w prawie kanonicznym, Lublin 1936, s. 35-41.

18 C. 3, q. 7, c. 1 .

19 X. 2, 27, 24; X. 1, 3, 22.

20 Por. E. Petit, Consentement matrimonial et fiction de droit. Etude sur l'efficacité juridique de consentement après l'introduction de la fiction en droit canonique, Roma 2010, s. 302-308.

21 Por. R. Interland, L'estensione dell'istituto della supplenza alla facoltà ministeriali (can. 144 \$ 2), Periodica 108 (2019), s. 375-376.

22 Szerzej na ten temat zob. F. López IllanA, La suplencia de la facultad asistir al matrimonio, w: R. RodríGEZ-OCAÑa (red.), Forma jurídica y matrimonio canónico, Pamplona 1998, s. 117-122; J. DoHNALIK, Znaczenie zasady ,supplet Ecclesia”. Od kan. 209 KPK z 1917 roku do kan. 144 obecnego KPK - interpretacja $i$ aplikacja, Prawo Kanoniczne 60 (2017), nr 4, s. 16-33; A. Tunia, Kształtowanie się formy kanonicznej zawarcia małżństwa, Roczniki Nauk Prawnych 18 (2008) nr 1, s. 130-146; D. CzUPRYŃSKI, Uzupełnienie upoważnienia do asystowania przy zawieraniu mał̇̇enstwa. Studium kanoniczno-dogmatyczne. Warszawa 2007, s. 61-95. 
i powszechnie uznawany za tytuł prawdziwy, ponieważ z powodu błędu powszechnego i dobra publicznego prawo uzupełniało brak tytułu ${ }^{23}$.

Początkowo uzupełnienie jurysdykcji rozumiano jako uzupełnienie władzy zwyczajnej, i dlatego poszukiwano koniecznie jakiegoś tytułu, który, jeśli nie był prawdziwy, jako nadany z błędem, który czynił go nieważnym, powinien być przynajmniej pozorny i oczywisty. Z biegiem czasu utarła się opnia, w myśl której jeśli uzupełnienie przynosi dobro wspólnocie, może dokonywać się bez żadnego tytułu albo przy istnieniu tytułu domniemanego czy zwykłym posiadaniu urzędu, pod warunkiem że nie jest znany charakter nielegalny takiego posiadania. Jeśli de facto uzupełnienie jurysdykcji służy dobru wspólnoty, to nie widać powodu, dla którgo byłby konieczny tytuł ${ }^{24}$.

Pierwotnie zatem utrzymywano, że uzupełnienie jurysdykcji (uprawnienia) dokonuje się, gdy istnieje tytuł pozorny, następnie nawet domniemany, wreszcie nie przywiązuje się żadnej wagi do tytułu. Można więc przyjąć, że uzupełnienie dotyczy nie tylko władzy zwyczajnej, lecz również delegowanej; początkowo przyjmowano, że jedynie delegowanej ogólnie (ad universitatem causarum), następnie zaś, że również delegowanej do poszczególnych przypadków (ad singulos casus) ${ }^{25}$.

Kierując się dążeniem do jak najdalej idącego ograniczenia przypadków nieważności małżeństwa $\mathrm{z}$ powodów formalnych, na początku prac kodyfikacyjnych podjętych po Soborze Watykańskim II, konsultorzy Zespołu De matrimonio Papieskiej Komisji do Rewizji KPK uzupełnienie uprawnienia, o którym mowa, uważali za niewystarczające $\mathrm{z}$ powodu bardzo szerokiej interpretacji błędu powszechnego ${ }^{26}$. Schemat soborowy De matrimonio przewidywał ważność małżeństwa zawieranego przed jakimkolwiek kapłanem, jeśli nie pozostawał w karach kościelnych a małżeństwo było zawarte

23 M.A. Ortíz, La supplenza di facoltà per assistere al matrimonio..., dz. cyt., s. 61.

24 V. De Paolis, Delega e supplenza di potestà per assistere al matrimonio, w: P.A. Bonnet, C. Gullo (red.), Diritto matrimoniale canonico, t. 3: La forma, gli effetti, la separazione, la convalida, Città del Vaticano 2005, s. 69.

25 Por. M.A. Ortíz, La supplenza di facoltà per assistere al matrimonio..., dz. cyt., s. 61-62.

26 Por. E. Petit, Consentement matrimonial et fiction de droit..., dz. cyt., s. 313-314. 
w kościele lub w publicznej kaplicy. Wiedząc, że nierzadko małżeństwa są zawierane - z powodu ignorancji, zaniedbania czy niewiedzy bez należytego upoważnienia kapłana, i chcąc powstrzymać ryzyko zawierania wielu małżeństw nieważnych, ojcowie soborowi zaproponowali rozwiązanie, w myśl którego jeśli zdarzy się, że małżeństwo zostało zawarte wobec kapłana, który nie miał wymaganej delegacji do asystowania przy jego zawieraniu, na mocy postanowienia Soboru, małżeństwo takie należy uznać za ważne, jeżeli w stosunku do kapłana nie zapadł wyrok ekskomuniki albo interdyktu czy suspensy lub kara taka nie została zdeklarowana, a małżeństwo zostało zawarte w kościele lub w oratorium publicznym ${ }^{27}$.

W rezultacie propozycja ta znalazła swój wyraz w następującym sformułowaniu: „Małżeństwo zawarte wobec kapłana, niezgodnie z przepisami prawa, należy uznać za ważne, byleby kapłan nie był ukarany wyrokiem ekskomuniki albo interdyktu albo suspensy lub kara taka nie została zadeklarowana albo biskup nie wydał kapłanowi zakazu (asystowania przy zawieraniu małżeństw), a małżeństwo zostało zawarte w kościele lub w oratorium publicznym"28.

Sugestię tę brano pod uwagę podczas prac nad rewizją KPK z 1917 roku $^{29}$. Konsultorzy Zespołu De matrimonio zaproponowali dodanie do kan. 1096 KPK nowego paragrafu, który brzmiał następująco: „Ważna jest umowa małżeńska gdy przy jej zawarciu asystuje kapłan (lub diakon), który nie ma delegacji, jeśli małżeństwo jest zawarte (w świętym obrzędzie) w kościele lub w oratorium publicznym,

\footnotetext{
27 Concilio Vaticano II, Acta Synodalia Sacrosancti Concilii Oecumenici Vaticani II, t. 3: Periodus Tertia, Pars VIII: Congregationes Generales CXXIII-CXXVII. Sessio publica V, Città del Vaticano 1976, s. 1074.

28 ,Matrimonium contractum coram sacerdote, contra iuris praescripta, validum declaretur, dummodo sacerdos non sit per sententiam excommunicatus vel interdictus vel suspensus aut talis declaratus vel ab Episcopo prohibitus, et matrimonium in ecclesia vel oratorio publico celebretur”. TAMżE, s. 470.

29 Por. Communicationes 3 (1971), s. 79.
} 
a asystujący nie ma zakazu od władzy kościelnej asystowania przy zawieraniu małżeństw"30.

Propozycja ta, choć pozwalała uniknąć zgorszenia wiernych stwierdzeniem nieważności małżeństwa z przyczyn formalnych, wywołała w gronie konsultorów pewne wątpliwości, m.in. z uwagi na to, iż takie rozwiązanie czyniłoby zbędnym regulację dotyczacą udzielania delegacji. W związku z tym relator Zespołu Konsultorów przedstawił inny tekst, w którym zaproponował rodzaj uważnienia w zawiązku małżeństw zawartych przed kapłanem nie mającym uprawnienia: „Umowę małżeńską zawartą w obecności kapłana lub diakona, który nie ma uprawnienia do asystowania, Kościół uważnia w zawiązku od momentu jej zawarcia, jeśli kontrahenci rozumnie sądzą, że kapłan lub diakon jest zdolny do asystowania przy zawieraniu małżeństwa"31.

W ten sposób w zaproponowanym kanonie pojawiła się interpretacja błędu powszechnego, który jest podstawą do uzupełnienia uprawnienia, w myśl której wystarczy, że małżonkowie rozumnie uważają, iż asystujacy duchowny jest kompetentny do asystowania przy zawarciu małżeństwa.

Tego rodzaju interpretacja nie była jednak zdolna uchylić wątpliwości dotyczących znaczenia owego błędu, przede wszystkim dlatego, że wprowadzała element subiektywny: rozumne przekonanie kontrahentów o zdolności kapłana do asystowania. Z interwencji członków Zespołu Konsultorów wynika, iż kierując swoją uwagę ku instytucji uważnienia, niemal jednomyślnie opowiedzieli się za uczynieniem ważnym małżeństwa, którego nieważność pochodziła z przyczyn techniczno-formalnych, pod warunkiem, że kapłan lub diakon nie

\footnotetext{
30 „Valet matrimonii contractus assistente sacerdote (vel diacono) qui delegatione caret, dummodo matrimonium celebratur (ritu sacro) in ecclesia vel oratorio publico et assistens ab auctoritate ecclesiastica non sit prohibitus ne matrimonio assistat". Communicationes 33 (2001), s. 264.

31 „Matrimonii contractus assistente sacerdote vel diacono, facultate assistendi carente, Ecclsia a momento celebrationis in radice sanat, dummodo contrahentes rationabiliter putant sacerdotem vel diaconum idoneum esse ad matrimonio assistendum”. TAMżE, s. 265.
} 
był dotknięty zakazem asystowania, a małżeństwo zostało zawarte w miejscu świętym. Po dyskusji członkowie wymienionego Zespołu ${ }^{32}$, w schemacie z 1975 roku zaproponowali dwa teksty alternatywne kanonu 315. Pierwszy z nich brzmiał: „Małżeństwo zawarte przed kapłanem lub diakonem, który nie miał uprawnienia do asystowania, Kościół uzdrawia w zawiązku od momentu zawarcia związku, byleby małżeństwo było zawarte wobec dwóch świadków w kościele lub kaplicy, a asystujący nie miał od władzy kościelnej zakazu asystowania przy zawieraniu małżeństwa"33.

Natomiast drugą wersję sformułowano następująco: „W błędzie powszechnym, faktycznym lub prawnym, podobnie w wątpliwości pozytywnej i prawdopodobnej, czy to prawnej czy faktycznej, uprawnienie do asystowania przy zawieraniu małeństwa uzupełnia Kościół"34.

Toczące się dyskusje dotyczące wątpliwości co do pierwszej z zaproponowanych formul ${ }^{35}$ doprowadziły, iż w Schemacie z 1980 roku wybrano drugą wersję kanonu, uznaną za wystarczającą „do uchylenia wątpliwości o ważności małżeństwa" ${ }^{36}$, przez przyjęcie uzupełnienia uprawnienia w przypadku błędu powszechnego oraz wątpliwości pozytywnej i prawdopodobnej $^{37}$. Z kolei w Schema Novissimum z 1982 roku zachowano wersję, w której przyjęto wyraźnie uzupełnienie

\footnotetext{
32 TAMżE, s. 265-266.

33 „Matrimonium contractum assistente sacerote vel diacono, facultate assistendi carente, Ecclesia a momemnto celebrationis in radice sanat, dummodo matrimonium celebretur coram duobus testibus in ecclesia vel oratorio et assistens ab auctoritate ecclesistica non sit prohibitus ne matrimonio assistat". Pontificia Commissio Codici Iuris CANonici Recognoscendo, Schema documenti pontificii de disciplina canonica de Sacramentis recognoscitur, Typis Polyglottis Vaticanis 1975, can. 315.

34 „In errore communi de facto aut de iure, itemque in dubio [positivo et probabile, sive iuris sive facti, facultatem assistendi supplet Ecclesia”. TAMŻE.

35 Por. Communicationes 10 (1978), s. 90.

36 Por. TAMżE.

37 Por. Pontificia Commissio Codici Iuris Canonici Recognoscendo, Schema documenti pontificii de disciplina canonica de Sacramentis recognoscitur, Typis Polyglottis Vaticanis 1980, can. 1068.
} 
uprawnienia $^{38}$, choć w tekście definitywnie promulgowanym w 1983 roku ograniczono się do odesłania do kan. 144, 1108 i 1111 KPK.

Ostatecznie, usiłowania uznania ważności małżeństw zawartych przed jakimkolwiek kapłanem lub diakonem zakończyły się sprowadzeniem kwestii do odnowionej aplikacji normy o uzupełnieniu jurysdykcji do uzupełnienia uprawnienia do asystowania przy zawieraniu małżeństwa. W istocie, konsultorzy Zespołu De matrimonio uznali za wystarczające - w celu uniknięcia mnożenia małżeństw nieważnych z braków formalnych - rozciągnięcie zarówno instytucji delegacji, jak i aplikacji kan. 144 KPK, a także wyjęcie od obowiązku zachowania formy kanonicznej tych, którzy formalnym aktem odstąpili od Kościoła (kan. 1117 KPK) ${ }^{39}$.

\section{Uzupełnienie uprawnienia do asystowania przy zawieraniu} małżeństwa w sytuacji błędu powszechnego, a także wątpliwości pozytywnej i prawdopodobnej oraz podstawa uzupełnienia

Stosownie do kan. $144 \$ 1-2 \mathrm{KPK}$, uzupełnienie uprawnienia do asystowania przy zawieraniu małżeństwa ma miejsce w dwóch przypadkach: błędu powszechnego oraz wątpliwości pozytywnej i prawdopodobnej. Nie chodzi tu jednak o uważnienie aktu nieważnego, lecz o uzupełnienie przez Kościół braku uprawnienia, o którym mowa.

Gdy chodzi błąd powszechny, to zachodzi on wówczas, gdy ogół wiernych danej społeczności jest przekonany, że dany podmiot, który asystuje przy zawieraniu małżeństwa ma po temu uprawnienie, gdy w rzeczywistości go nie ma. Tego rodzaju błąd, jak zaznaczono w kan. $144 \$ 1 \mathrm{KPK}$, może być zarówno faktyczny, jak i prawny.

Błąd faktyczny zachodzi wtedy, gdy ogół wiernych rzczywiście żywi fałszywe przekonanie o tym, że asystujący przy zawieraniu

\footnotetext{
38 Zob. Pontificia Commissio Codici Iuris Canonici Recognoscendo, Schema novissimum. Iuxta placita Patrum Commissionis emendatum atque Summo Pontifici praesentatum, Typis Polyglottis Vaticanis 1982, can. 1114; Por. także M.A. OrTíz, La supplenza di facoltà per assistere al matrimonio..., art. cyt., s. 56-57.

39 Por. Dec. C. Stankiewicz z 15.12.1992, RRD 84 (1992), s. 671-672.
} 
danego małżeństwa ma po temu kompetencje (niezbędne uprawnienie). Przemiotem błędu może być nie tylko uprawnienie kapłana lub diakona, lecz również zakres terytorialny tegoż uprawnienia ${ }^{40}$.

Natomiast błąd powszechny jest prawny, gdy okoliczności (pewne i oczywiste) o charakterze publicznym związane z osobą duchownego bądź wykonywaniem przez niego funkcji same przez się mogą i powinny spowodować u ogółu wiernych błędne przekonanie o posiadaniu przezeń uprawnienia; jest to więc błąd domniemany, czyli możliwość zaistnienia błędnego przekonania ${ }^{41}$; niekiedy taki błąd jest określany mianem błędu wirtualnego. Czymś drugorzędnym jest fakt skutecznego popadnięcia w błąd przez nielicznych czy licznych wiernych, ważne jest, że istnieje motyw wystarczający, by ogół wiernych mógł popaść w błąd ${ }^{42}$.

Co się tyczy wątpliwości pozytywnej i prawdopodobnej, która może być również prawna lub faktyczna, to dotyczy ona świadka urzędowego, który nie ma pewności co do uprawnienia do asystowania przy zawieraniu małżeństwa. Wątpliwość ta powinna być pozytywna, a więc nieoparta na ignorancji lub zaniedbaniu. Ponadto powinna być prawdopodobna, czyli mająca swoje źródło w uzasadanionych racjach, inaczej motywach, które przemawiają za posiadaniem uprawnienia, choć nie dają pewności; jeśli racje nie są uzasadnione, wątpliwość nie jest prawdopodobna.

Jak wspomniano, wątpliwość pozytywna i prawdopodobna może być prawna lub faktyczna - w zależności od tego, czy się odnosi do podstawy prawnej, a więc do norm dotyczących asystowania przy zawieraniu małżeństwa, czy też do ich aplikacji do konkretnego przypadku³

\footnotetext{
40 M.A. Ortíz, La supplenza di facoltà per assistere al matrimonio..., dz. cyt., s. 58.

41 F. BĄczkowicz, Prawo kanoniczne. Podręcznik dla duchowieństwa, 1. 1, przygotowali do druku i uzupełnili: J. Baron, W. Stawinoga, Opole 1957, s. 434; Dec. C. Mattioli z 15.12.1960, SRRD 52 (1960), s. 320.

42 Por. M.A. Ortíz, La supplenza di facoltà per assistere al matrimonio..., dz. cyt., s. 58.

43 TAMŻE.
} 
Wątpliwość, o której mowa, pozytywna i prawdopodobna, powinna być per se zdolna do spowodowania błędu, wskutek czego sytuacja wątpliwości nie byłaby czymś innym niż szczególnym przypadkiem błędu powszechnego ${ }^{44}$.

Gdy chodzi o podstawę uzupełnienia uprawnienia do asystowania przy zawieraniu małżeństwa, to niektórzy przedstawiciele doktryny utrzymują, że tkwi ona nie tyle w udzieleniu tegoż uprawnienia, ile w fakcie, iż sam Kościół działa bezpośrednio „,zastępując” działającego, któremu brak uprawnienia. Inni autorzy w uzupełnieniu uprawnienia upatrują rodzaj uważnienia przez prawo aktów nieważnych, dokonywanego przez sam Kościół. Jeszcze inni widzą w tej instytucji uważnienie jednoczesne wykonywania aktu: szafarz lub działający wykonuje substrakt aktu, który uzyskuje ważność ipso iure, co oznacza, że prawo byłoby tutaj przyczyną formalną ${ }^{45}$. W słynnym orzeczeniu z 15 grudnia 1992 roku c. Stankiewicz stwierdza się, że - jak przyjmuje powszechnie doktryna - uzupełnienie władzy rządzenia (podobnie jak uprawnienia do asystowania przy zawieraniu małżeństwa), nie polega na zastąpieniu działającego przez Kościół w dokonaniu aktu, o który chodzi, w sposób nieosobowy, lecz raczej na zastąpieniu brakującej jurysdykcji działającego przez jurysdykcję nadzwyczajną delegowaną przez prawo, udzieloną działającemu w samym akcie jurysdykcyjnym udzielonym przejściowo przez Kościół ${ }^{46}$.

Należy dodać, że w każdym przypadku uzupełnienie uprawnienia implikuje pewną fikcję. Tak więc w sytuacji błędu powszechnego

\footnotetext{
44 C.J. Errázuriz, Corso fondamentale sul diritto della Chiesa, Milano 2009, s. 334. 45 A. Nita, La suplencia de la facultad de asistir al matrimonio en caso de eror común, a la luz de la jurisprudencia de la Rota Romana, Ius Canonicum 39 (1999), s. 670 .

46 „Notanum est tamen suppletionem iurisdictionis seu potestatis regiminis, prout doctrina communis docet, non consistre in substitutione ipsius agentis, in perficiendo actu de quo agitur, per Ecclesiam modo impersonali loco agentis procedentem, sed potius in substitutione deficientis iurisdictionis agentis per iurisdictionem extraordinariam iure delegatam, ab Ecclesia agenti in ipso actu iurisdictionali perficiendo transeunter concessam”. Dec. C. STANKIEWICZ z 15.12.1992, RRD 84 (1992), s. 670.
} 
(prawnego lub faktycznego), podobnie jak wątpliwości pozytywnej i prawdopodobnej, sam Kościół uzupełnia brak uprawnienia do asystowania przy zawieraniu małżeństwa wymaganego przez kan. 1108 KPK, wskutek czego małżeństwo staje się ważne. W stosowaniu instytucji uzupełnienia uprawnienia zakłada się istnienie u nupturientów prawdziwej woli małżeńskiej, która z uwagi na brak wymogu formalnego byłaby nieskuteczna. Można powiedzieć, że stosując uzupełnienie braku uprawnienia (podobnie jak braku jurysdykcji), Kościół kieruje się humanizmem, co znamionowało w tym zakresie już prawo rzymskie ${ }^{47}$.

\section{Uzupełnienie uprawnienia w orzecznictwie Roty Rzymskiej}

Aplikacja kan. $144 \$ 2$ KPK do konkretnych przypadków asystowania przez duchownych przy zawieraniu małżeństwa, wnoszonych na forum sądowe, bynajmniej nie jest łatwa i może nasuwać szereg wątpliwości i trudności. Świadczyć o tym może orzecznictwo Roty Rzymskiej, w którym nie brak ciągłego poszukiwania odpowiedzi na nurtujące sędziów pytania, podobnie zresztą jak i w doktrynie kanonicznego prawa małżeńskiego.

Współczesna judykatura rotalna dotycząca braku formy kanonicznej ma co najmniej dwie znaczące charakterystyczne cechy: $\mathrm{z}$ jednej strony szczupłość spraw rozpoznawanych z wymienionego tytułu, zarówno gdy chodzi o liczbę decyzji (0,29\%), jak i różnorodność spraw sprowadzających się niemal wyłącznie do uzupełnienia uprawnienia do asystowania przy zawieraniu małżeństwa, $\mathrm{z}$ drugiej zaś wszystkie

\footnotetext{
47 Prawo Barbarius Ulpiana uznawało za ważne akty sługi, który ukrył swój status i pełnił godność pretora. Uważało się, że jego akty są ważne nie dlatego, że zostały spełnione w dobrej wierze, lecz z uwagi na dobro tych, do których były one skierowane przez pseudo pretora; tak było bowiem „,bardziej humanitarnie”. Por. F.A. Wilches, De errore communi in iure romano et canonico, Washington 1940, s. 68-77; E. Petit, Consentement matrimonial et fiction de droit..., dz. cyt., s. 306-308.
} 
wyroki mają praktycznie za punkt koniecznego odniesienia wyrok c. Stankiewicz z 22 grudnia 1992 roku $^{48}$.

Dobrą, jak się wydaje, ilustracją stanowiska wymienionego Trybunału Apostolskiego w interesującej nas kwestii mogą być m.in. jego cztery orzeczenia c. Stankiewicz z 15 grudnia $1992^{49}$, c. Pompedda z 14 lutego $1997 \mathrm{roku}^{50}$, c. Pinto z 5 lipca 2002 roku $^{51}$ oraz c. McKay z 27 października 2006 roku $^{52}$.

\subsection{Wyrok c. Stankiewicz z 15.12.1992 roku}

Orzeczenie c. Stankiewicz z 15 grudnia 1992 roku zapadło w sprawie dwojga katolików amerykańskich, którzy zawarli małżeństwo w 1980 roku przed kapłanem nie mającym uprawnienia do asystowania przy zawarciu małżeństwa, ponieważ nie pozostawał w pełnej jedności z Kościołem. Kapłan ten, narodowości hiszpańskiej, przeniósł się do Denver (U.S.A.), lecz nigdy nie miał przydzielonej funkcji duszpasterskiej, nie udzielono mu mu również uprawnień do pełnienia posługi; powiedziano mu nawet wprost, by nie błogosławił małżeństw dopóki Kuria Diecezjalna nie wyjaśni u Stolicy Apostolskiej jego statusu kanonicznego. Wbrew temu, duchowny ten pobłogosławił małżeństwo w jednym z sanktuariów (niefigurującym w wykazie sanktuariów archidiecezji), nawiedzanym przez wiernych „tradycjonalistów”, świadomych tego, że nie pozostają w pełnej jedności z Kościołem. Wierni ci musieli pokonać dość daleką drogę, by przybyć do sanktuarium. Poza tym w aktach stwierdzono, że rodzina jednej ze stron zawierających małżeństwo zerwała całkowicie relacje

\footnotetext{
48 M.A. OrTíz, La supplenza di facoltà per assistere al matrimonio nella giurisprudenza coram Stankiewicz. w: J. KowAL, J. Llobell (red.), Iustitia et iudicium. Studi di diritto matrimoniale e processuale canonico in onore di Antoni Stankiewicz, t. 2, Città del Vaticano 2010, s. 967-968.

49 Dec. C. Stankiewicz 15.12.1992, RRD 84 (1992), s. 664-679.

50 Dec. c. Pompedda z 14.02.1997, RRD 89 (1997), s. 103-113.

51 Dec. C. Pinto z 05.07.2002, RRD 94 (2002), s. 409-414.

52 Dec. C. McKay z 27.10.2006, RRD 98 (2006), s. 327-333.
} 
z jednym ze swoich krewnych, ponieważ zawarł małżeństwo w Kościele katolickim, i dlatego uważali, że żyje w grzechu ${ }^{53}$.

Po rozpadnięciu się małżeństwa i uzyskaniu przez strony rozwodu cywilnego, żona zwróciła się do Trybunału Kościelnego w Denver o stwierdzenie nieważności swojego małżeństwa $\mathrm{z}$ tytułu braku formy kanonicznej. Wikariusz sądowy podjął decyzję o prowadzeniu procesu dokumentalnego, a po wezwaniu stron i interwencji obrońcy węzła małżeńskiego, w dniu 6 kwietnia 1989 roku orzeczono nieważność małżeństwa. Wyrok, wydany na podstawie kan. $1686 \mathrm{KPK}$, podlegał natychmiastowemu wykonaniu, jeśli nie złożono by apelacji. Tymczasem powódka zwróciła się do Dziekana Roty Rzymskiej prosząc, by wymieniony Trybunał Apostolski wypowiedział się co do innej causa petendi, ponieważ ów kapłan, który asystował przy zawieraniu małżeństwa przekonał ją, iż posiadał „jurysdykcję uzupełniającą”, którą przewiduje prawo w przypadku błędu powszechnego i wątpliwości pozytywnej i prawdopodobnej ${ }^{54}$.

Trybunał Roty Rzymskiej sprawę podjął, a obrońca węzła małżeńskiego, dla uniknięcia wszelkiej wątpliwości co do prawomocności skargi powódki, złożył apelację, która została podjęta wraz z prośbą o potwierdzenie wyroku pierwszej instancji zawartą w piśmie tejże kobiety skierowanym do przyznanego jej ex officio patrona. Turnus rotalny określił formułę wątpliwości: Czy wyrok Trybunału w Denver 6 kwietnia 1989 roku, wydany na podstawie kan. 1686 KPK, należy zatwierdzić czy też rozpoznać sprawę w trybie zwykłym. 15 grudnia 1992 roku turnus odpowiedział pozytywnie na pierwsze dubium i negatywnie na drugie, a więc potwierdzając orzeczenie pro nullitate pierwszej instancji ${ }^{55}$.

W orzeczeniu c. Stankiewicz sygnalizuje się, iż prawo naturalne wymaga jedynie prawidłowej zgody małżeńskiej nupturientów, która powinna być „wyrażona zgodnie z prawem” (kan. $1057 \$ 1 \mathrm{KPK}$ ).

\footnotetext{
53 A. Nita, La suplencia de la facultad de asistir al matrimonio en caso de eror común..., dz. cyt., s. 661-662.

54 TAMŻE, s. 662.

55 TAMŻE, s. 666.
} 
Z drugiej strony mówi się, że od Dekretu Tametsi Soboru Trydenckiego Kościół wprowadził formę kanoniczną ad validitatem, przyjętą następnie w Kodeksach Prawa Kanonicznego ${ }^{56}$.

W wyroku spotykamy następnie dwa doniosłe stwierdzenia, które stanowią klucz do interpretacji samej instytucji formy kanonicznej oraz instytucji uzupełnienia uprawnienia do asystowania przy zawarciu małżeństwa. Tak więc najpierw ponens wskazał na charakter instrumentalny formy kanonicznej, która służy prawdzie o zgodzie małżeńskiej, następnie zaś akcentuje funkcję społeczną formy małżeńskiej, właśnie dlatego, jak to stwierdził Jan Paweł II w przemówieniu do Roty Rzymskiej z 28 stycznia 1982 roku $^{57}$, że zgoda nupturientów jest ,„aktem kościelnym”, co więcej: jest istotnym jądrem znaku sakramentalnego, który - między ochrzczonymi - jest sakramentem. W rzeczywistości, dodał papież, konsens tworzy „Kościół domowy” i konstytuuje rzeczywistość sakramentalną, gdzie łączą się dwa elementy: element duchowy, jako wspólnota życia w wierze, w nadziei i w miłości, oraz element społeczny, jako społeczność zorganizowana, zhierarchizowana, żywa komórka społeczności ludzkiej, podniesiona do godności sacramentum magnum, Kościół Chrystusa, w którym sytuuje się jako Kościół domowy ${ }^{58}$.

Stwierdzenia te, jak zauwża M.A. Ortíz, dotyczące centralnego miejsca zgody małżeńskiej i jej wewnętrznego wymiaru społecznego i kościelnego, a także charakteru instrumentalnego „prawowitej formy”, służą z jednej strony „osadzeniu” funkcji formy małżeńskiej, która powinna być środkiem służącym prawdzie o małżeństwie, a $\mathrm{z}$ drugiej strony służą również podkreśleniu związku z dobrem wspólnym Kościoła w każdym małżeństwie ${ }^{59}$.

\footnotetext{
56 TAMżE, s. 666-667.

57 IoAnnes Paulus II, Allocutio ad Rotam Romanam diei 28 ianuarii 1982, AAS 74 (1982), s. 451.

58 TAMŻE.

59 M.A. Ortíz, La supplenza di facoltà per assistere al matrimonio nella giurisprudenza coram Stankiewicz..., dz. cyt., s. 973.
} 
Ponens zwraca następnie uwagę na rolę świadka urzędowego asystującego przy zawieraniu małżeństwa, na podstawie uprawnienia z urzędu lub delegacji (kan. 1108, 1109, 1111 KPK), przypomina też normę o jurysdykcji personalnej (kan. $1110 \mathrm{KPK}$ ). Wspomina następnie o debacie doktrynalnej na temat natury jurysdykcji oraz aktu asystowania przy zawieraniu małżeństwa. Zaznacza, że chodzi tu o akt, któremu Kościół daje wiarę dzięki obecności świadka urzędowego, analogicznie jak w systemach państwowych (dzięki obecności notariusza). Rola świadka kwalifikowanego obecnego przy zawieraniu małżeństwa nie jest jednak bierna i nie sprowadza się do roli świadczenia o akcie prawnym. Jest to rola o charakterze czynnym, który to zbliża do władzy jurysdykcyjnej, choć uprawnienie asystowania przy zawieraniu małżeństwa nie jest aktem jurysdykcyjnym sensu stricto, jest natomiast $\mathrm{z}$ pewnością aktem jurysdykcjonalnym, i dlatego to, co jest postanowione o jurysdykcji, obowiązuje również $\mathrm{w}$ zakresie asystencji małżeńskiej ${ }^{60}$. W konsekwencji do aktu tejże asystencji aplikuje się wiele norm odnoszących się do posiadania i przekazywania władzy jurysdykcyjnej ${ }^{61}$.

Jedną z norm dotyczących władzy jurysdykcyjnej, która znajduje swoje zastosowanie do uprawnienia asystencji małżeńskiej, stwierdza Stankiewicz, jest norma o uzupełnieniu jurysdykcji. Kan. 1108 obowiązującego KPK przyjmuje wyraźnie odniesienie do kan. 144 $\$ 1-2$. Kan. 209 KPK z 1917 roku, odpowiadający aktualnemu kan. 144, nie zawierał wyraźnego odniesienia do uprawnienia do asystowania przy zawieraniu małżeństwa jako przedmiotu uzupełnienia. Dopiero odpowiedź Papieskiej Komisji do Interpretacji KPK uznała aplikację do małżeństwa kan. 209 KPK z 1917 roku, choć judykatura rotalna aplikowała tę instytcję już przed 1952 rokiem $^{62}$.

\footnotetext{
60 Por. Dec. C. Bruno z 22.02.1980, RRD 72 (1980), s. 117.

61 M.A. ORTíz, La supplenza di facoltà per assistere al matrimonio nella giurisprudenza coram Stankiewicz..., dz. cyt., s. 975.

${ }^{62}$ A. Nita, La suplencia de la facultad de asistir al matrimonio en caso de eror común..., art. cyt., s. 661-708.
} 
Kwestia uzupełnienia uprawnienia do asystowania przy zawieraniu małżeństwa stanowi wątek najczęściej poruszany w orzecznictwie w obszarze formy kanonicznej. Instytucja owego uzupełnienia stanowi aplikację fundamentalnej zasady kanonicznego systemu małżeństwa, którą jest favor matrimonii.

Refleksja A. Stankiewicza nad aplikacją uzupełnienia uprawnienia do asystowania przy zawieraniu małżeństwa w obowiązującym prawie ma za punkt wyjścia rozpatrywanie tej instytucji w kontekście woli ustawodawcy ograniczenia do maximum nieważności małżeństwa z przyczyn formalnych, co też brano pod uwagę w posoborowych pracach nad rewizją i kodyfikacją prawa kanonicznego. Wymieniony ponens przypomina, że dalsze usiłowania zmierzające do uznania za ważne małżeństw zawartych przed jakimkolwiek kapłanem lub diakonem znalazły swój finał w sprowadzeniu ich do odnowionej aplikacji normy o uzupełnieniu jurysdykcji (kan. 144 KPK) do uprawnienia do asystencji małżeńskiej ${ }^{63}$. Mając na uwadze ograniczenie nieważności małżeństw, redaktorzy Zespołu De matrimonio uznali za wystarczające zarówno rozciągnięcie instytucji delegacji, jak i aplikację uzupełnienia uprawnienia z kan. 144. Jeśli doktryna i orzecznictwo spokojnie przyjęły aplikowanie uzupełnienia tegoż uprawnienia, to ponens w omawianej sprawie dodaje, że gdy chodzi o aplikowanie normy do poszczególnych przypadków, to nie zawsze jest łatwo określić, czy istnieją przesłanki dla uznania postaci błędu powszechnego albo wątpliwości pozytywnej i prawdopodobnej, w których to sytuacjach Kościół uzupełnia brak uprawnienia ${ }^{64}$.

Ówczesny dziekan Roty Rzymskiej wskazuje następnie w wyroku, w jakich warunkach ,działa” uzupełnienie uprawnienia do asystencji małżeńskiej. Stwierdza mianowicie, że - według brzmienia kan. 144 $\$ 1 \mathrm{KPK}$ w połączeniu $\mathrm{z}$ kan. $1111 \$ 1 \mathrm{KPK}$ - uzupełnienie to ma miejsce

\footnotetext{
63 Por. Communicationes 8 (1976), s. 33.

64 Dec. c. Stankiewicz 15.12.1992, RRD 84 (1992), s. 665; M.A. Ortíz, La supplenza di facoltà per assistere al matrimonio nella giurisprudenza coram Stankiewicz..., dz. cyt., s. 981.
} 
jedynie w przypadku braku uprawnienia zwyczajnego lub delegacji ogólnej, nie zaś w przypadku delegacji specjalnej ${ }^{65}$.

Jak zauważa M.A. Ortíz, należy przede wszystkim powiedzieć, że z połączonych odniesień do kan. 144, 1108 i 1111 KPK nie wydaje się czymś oczywistym, że ustawodawca chciał wyraźnie rozróżnić zakres uzupełnienia uprawnienia, który mógłby dotyczyć każdego uprawnienia: zwyczajnego lub delegowanego, ogólnego lub specjalnego. Natomiast Stankiewicz utrzymuje, broniąc m.in. tezy większościowej przyjmowanej w orzecznictwie, iż uzupełnienie uprawnienia nie znajduje zastosowania w przypadku braku delegacji specjalnej. Racje przemawiające za taką tezą dotyczą w istocie dwóch porządków: po pierwsze, stan ignorancji różni się od błędu, przewidzianego w kan. 144, po drugie, racją normy (o uzupełnieniu uprawnienia) jest ochrona dobra wspólnego, co wymaga obecności wystarczającego tytułu do wywołania błędu powszechnego ${ }^{66}$.

Niektórzy autorzy podają trzeci motyw dla wykluczenia stosowania uzupełnienia uprawnienia do braku delegacji specjalnej: byłby nim fakt, że kan. 144 odsyła do kan. $1111 \$ 1$, gdzie czyni się wzmiankę o delegacji ogólnej, a nie o specjalnej ${ }^{67}$. Jak stwierdza jednak V. De Paolis, wniosek ten wydaje się mało przekonujący, takie uchylenie bowiem w kan. 144 i $1111 \$ 1$ KPK nie jest restrykcyjne, ponieważ w tym ostatnim nie uwzględnia się jedynie delegacji ogólnej, lecz obydwie: czyni się wyraźną wzmiankę o delegacji ogólnej („etiam generalem”) właśnie dlatego, że kanon zamierza poszerzyć możliwość udzielenia wspomnianej delegacji ogólnej, bardzo ograniczonej w KPK z 1917 roku. Kan. $1111 \$ 1 \mathrm{KPK}$ nie tylko nie ogranicza uzupełnienia do delegacji ogólnej, lecz wyraźnie je rozciąga na jakąkolwiek delega-

\footnotetext{
65, ,... s suppletio enim iuxta tenorem can. $144 \$ 2$ coll. cum can. $1111 \S 1$ obvenit tantum in casu defectus facultatis ordinariae vel facultatis delegatae generalis, minime vero in casu delegationis particularis". DeC. C. STANKIEWICZ 15.12.1992, RRD 84 (1992), s. 667.

${ }^{66}$ M.A. ORTÍz, La supplenza di facoltà per assistere al matrimonio nella giurisprudenza coram Stankiewicz..., dz. cyt., s. 981-982.

67 Por. A. Авате, Il matrimonio nella nuova legislazione canonica, Brescia 1985, s. 145.
} 
cję, a więc i na delegację specjalną, jak to zresztą uczyniła Papieska Komisja do Interpretacji KPK w 1952 roku i jak przyjmowano w powszechnej doktrynie. Wymieniony autor dodaje, iż po odpowiedzi Papieskiej Komisji z 1952 roku należy przyjąć uzupełnienie każdego rodzaju delegacji właśnie dlatego, że w odpowiedzi tej nie rozróżnia się delegacji ogólnej i specjalnej ${ }^{68}$.

Gdy chodzi o racje Stankiewicza i przeważajacej części orzecznictwa przemawiającej za zanegowaniem stosowania uzupełnienia uprawnienia asystencji małżeńskiej w stosunku do braku delegacji specjalnej, to na pierwszym miejscu wskazuje się różnicę zachodzącą między błędem a ignorancją. W wysuwaniu zasad, które rządzą uzupełnieniem uprawnienia, zauważa M.A. Ortíz, ponens podkreśla, iż wierni powinni znajdować się w stanie błędu powszechnego, czyli sądu moralnie pewnego o prawowitym posiadaniu koniecznego uprawnienia udzielonego przez Kościół duchownemu asystującemu przy zawieraniu małżeństwa, choćby taki sąd, oparty na fałszywej znajomości spraw, nie odpowiadał prawdzie ${ }^{69}$.

Bezpośrednio po tym stwierdzeniu ponens dodaje, że stanu błędu nie można mylić z innymi stanami umyłu, przede wszystkim z ignorancją i niewiedzą, choć w obszarze tym o ignorancji we właściwym sensie poznawczym nie może być mowy, zważywszy, że nie chodzi tu o brak należytej wiedzy w zgromadzeniu społeczności ${ }^{70}$. Dla podtrzymania tezy o braku znaczenia ignorancji lub niewiedzy dla skutków uzupełnienia uprawnienia do asystencji małżeńskiej Stankiewicz podkreśla, że w takim stanie nie podejmuje się żadnego sądu, ani prawdziwego ani fałszywego co do posiadania uprawnienia; odwołuje

\footnotetext{
68 V. De Paolis, Delega e supplenza di potestà per assistere al matrimonio..., dz. cyt., s. 75-76.

69 Dec. C. StankiewiCZ 15.12.1992, RRD 84 (1992), s. 668.

70 TAMŻE.
} 
się przy tym do niektórych orzeczeń rotalnych ${ }^{71}$ oraz do fragmentu „De Malo” św. Tomasza z Akwinu ${ }^{72}$.

Tego rodzaju rozróżnienie między błędem, który - jak się utrzymuje - polega na fałszywym sądzie o rzeczy, a ignorancją, którą określa się jako brak poznania, spotyka się często w orzecznictwie. W praktyce jednak błąd i ignorancja są ze sobą powiązane i bardzo często terminy te używane są zamiennie ${ }^{73}$. Nierzadko w judykaturze przyjmuje się, że ignorancja może być źródłem błędu ${ }^{74}$. Niekiedy też spotyka się stwierdzenie, w myśl którego „przy zachowaniu zasady, że z ignorancji często powstaje błąd, niejednokrotnie z błędu wynika ignorancja"75.

Należy pamiętać, że przekonanie o kompetencji świadka kwalifikowanego nie zawsze pochodzi z wyraźnego sądu o fakcie, lecz często ma swoje źródło po prostu w ignorancji: gdy kapłan błogosławi w kościele małżeństwo, ogół tam obecnych uważa go za kompetentnego. W rzeczywistosci, wierni zazwyczaj nie wiedzą, że kapłan powinien zwrócić się o autoryzację do władzy, lecz uważają, że może asystować przy zawieraniu małżeństwa. Ignorancja wiernych nie jest błędem, lecz staje się nim, odkąd wierni sądzą, że kapłan dysponuje uprawnieniem. Wydaje się, że duchowny występując publicznie, ubierając się w szaty liturgiczne, itp., stwarza okoliczności sprawiające popadnięcie przez ogół wiernych w błąd co do jego uprawnienia ${ }^{76}$.

71 Por. Dec. C. Teodori z 11.06.1949, SRRD 41 (1949), s. 289; Dec. C. Huot z 24.05.1973, SRRD 65 (1973), s. 472.

72 Akwinata wypowiada się o ignorancji stwierdzając, że może istnieć ignorancja bez tego, że ktoś wypowiada sąd o sprawach mu nieznanych, i wówczas mamy do czynienia $z$ ignorantem, a nie z tym, kto jest w błędzie. Lecz gdy wypowiada fałszywy sąd o tym, czego nie zna, wówczas słusznie mówi się, że jest w błędzie. Thomas Aquinas, De Malo, q. 3, a. 7.

73 „Error et ignorantia saepisime promiscue accipi solet”. DEC. C. PECORARI z 03.12.1942, SRRD 34 (1942), s. 840.

74 Por. Dec. C. Brennan z 30.06.1948, SRRD 40 (1948), s. 261.

75 „Attamen, firmo principio quod ex ignorantia saepe error, atque ex errore non raro ignorantia sequatur”. DEC. C. FIORE z 09.02.1962, SRRD 54 (1962), s. 34.

76 M.A. ORTíz, La supplenza di facoltà per assistere al matrimonio nella giurisprudenza coram Stankiewicz..., dz. cyt., s. 984-985. 
Druga racja przytoczona przez Stankiewicza przeciwko aplikowaniu uzupełnienia uprawnienia do przypadku delegacji specjalnej pozostaje w relacji do tytułu zdolnego do wprowadzenia w błąd wspólnotę wiernych i dobra, które uzupełnienie uprawnienia chroni. „Błąd zaś powszechny, stwierdza wymieniony ponens, również stosownie do nowego prawa, powinien powstać na podstawie faktu publicznego, który z natury swojej jest zdolny do spowodowania u wspólnoty wiernych przekonania, że asystujący przy zawieraniu małżeństwa posiada rzeczywiście konieczne do tego upoważnienie"77.

W tym znaczeniu, stwierdza M.A. Ortíz, judykatura rotalna w swojej większości przyjmuje, że w przypadku braku delegacji specjalnej, koniecznej do asystowania przy zawarciu określonego małżeństwa, nie można odwołać się do uzupełnienia uprawnienia, ponieważ nie wchodzi wówczas w grę dobro wspólne, lecz jedynie dobro partykularne nupturientów ${ }^{78}$. Gdy brak jest poza tym tytułu pozornego (titulus coloratus), brakowałoby przyczyny, która mogłaby wprowadzić w błąd ogół wiernych; nastapiłoby to jedynie w stosunku do niewielu, którzy nie reprezentują chronionego dobra publicznego ${ }^{79}$.

Stankiewicz wyjaśnia, że aby uzupełnienie uprawnienia osiągnęło swój skutek, wymaga się, by asystujący przy zawieraniu małżeństwa spełniał urząd w parafii, sanktuarium, itp., nawet pomocniczy, lecz taki, który „przekonywałby” wiernych, że ma konieczne uprawnienia ${ }^{80}$. Takie okoliczności, jak stała obecność duchownego w parafii,

\footnotetext{
77 „Error autem communis etiam iuxta tenorem nova ligis scaturiatur oportet e facto publico, quo natura sua aptum sit inducendi communitatem fidelium ad credendum matrimonio assistentem faculate ad hoc necesario revera potiri". DEc. C. STANKIEWICZ 15.12.1992, RRD 84 (1992), s. 669.

78 Por. Dec. C. Pinto z 11.12.1972, SRRD 64 (1972), s. 757.

79 M.A. ORTíz, La supplenza di facoltà per assistere al matrimonio nella giurisprudenza coram Stankiewicz..., dz. cyt., s. 985.

80 „Quare ut suppletio sortiatur suum effectum requiritur ut matrimonio asistens, sacerdos vel diaconus, munus aliquod, etiamsi auxiliare, in paroecia vel in alio sanctuario exerceat, quod saltem in apparentia inducere valet fideles in persuasionem de legitimo possessu ab illo necessariae facultatis". DeC. C. STANKIEWICZ 15.12.1992, RRD 84 (1992), s. 669.
} 
wywołują błąd powszechny faktyczny (de facto), jeśli w błąd popadnie wielu wiernych, albo błąd prawny (error iuris), inaczej wirtualny, o ile okoliczności stanowią element, który per se może doprowadzić wspólnotę wiernych do przekonania, że kapłan lub diakon jest wyposażony w należyte uprawnienie, nawet jeśli w konkretnym przypadku jedynie niektórzy myśleli pozytywnie (że duchowny posiada uprawnienie). W konsekwencji judykatura przyjmuje, iż błąd może się zweryfikować jedynie wówczas, gdy dotyczy kapłana, do którego wierni zwykli się zwracać. W praktyce zazwyczaj nie zachodzi błąd powszechny faktyczny, i dlatego z reguły nie ma miejsca uzupełnienie uprawnienia, kiedy chodzi o duchownego „z zewnątrz” i nieznanego wspólnocie ${ }^{81}$.

U podstaw tak restrykcyjnej konkluzji stoi przekonanie, że uzupełnienie uprawnienia służy dobru wspólnemu, co ma miejsce w odniesieniu do delegacji ogólnej. Za M.A. Ortízem można jednak pytać, czy dobro wspólne odnosi się tylko do wspólnoty, czy również do pojedynczego małżeństwa, wszak to ostatnie stanowi Kościół domowy. W przypadku małżeństwa należy więc uchylić rozróżnienie między dobem wspólnym i dobrem prywatnym; również ochrona pojedynczego małżeństwa stanowi niewątpliwie dobro wspólne ${ }^{82}$.

W orzeczeniu c. Stankiewicz, o którym mowa, chodzi o kontrahentów, którzy zwrócili się do kapłana, który nie zachowywał pełnej jedności z Kościołem. Jak wspomniano, duchowny ten oświadczył, że działa na podstawie „jurysdukcji uzupełnionej” w sytuacji błędu powszechnego oraz wątpliwości pozytywnej i prawdopodobnej.

Ponens rotalny przyjął, że tego rodzaju pretekst był nieuzasadniony, ponieważ w rozpoznawanym przypadku brak było uzupełnienia uprawnienia, ów asystujący kapłan nie pozostawał bowiem w pełnej jedności z Kościołem, a wierni zwrócili się do niego właśnie dlatego, że kontestował władzę biskupa ${ }^{83}$.

81 Zob. Dec. c. Caberletti z 12.06.2003, RRD 95 (2003), s. 75-76.

82 M.A. ORTíz, La supplenza di facoltà per assistere al matrimonio nella giurisprudenza coram Stankiewicz..., dz. cyt., s. 986.

83 „Nulla suppletio facultatis assistendi matrimonio dari potest, si asistens, etiamsi fuisset valide ordinatus presbyter, nullam communionem hierarchicam cum 
W takim przypadku, stwierdza ponens w konkluzji, nie chodzi ani o błąd powszechny ani o wątpliwość pozytywną i prawdopodobną, lecz co najwyżej miała tutaj miejsce zwykła ignorancja ze strony wiernych działających w dobrej wierze poza prawdą, w szczególności zaś ignorancja $\mathrm{w}$ najwyższym stopniu (crassa et supina) ze strony prezbitera co do istnienia uprawnienia, o czym sądził w złej wierze ${ }^{84}$.

A.M. Ortíz zauważa, że abstrahując od kwestii dobrej lub złej wiary kapłana (co do której trudno jest wydać osąd) i od błędu lub ignorancji wiernych, które abstrakcyjnie mogłyby być zasymilowane ${ }^{85}$, stajemy wobec pozytywnej woli podporządkowania się jurysdykcji Kościoła. Ponens bowiem stwierdza, że Kościół nie może uzupełnić uprawnienia temu, kto odstąpił od wspólnoty kościelnej i ośmielił się dokonać celebracji małżeństwa na na własna rękę, poza wspólnotą hirarchiczną z biskupem miejsca ${ }^{86}$.

Zaprezentowane zwięźle orzeczenie c. Stankiewicz z 15 grudnia 1992 roku ukazuje nie tyle problem uzupełnienia uprawnienia do asystencji małżeńskiej, ile uczula na kwestię chęci działania poza jurysdykcją Kościoła. Zarówno kapłan, jak i narzeczeni oraz ich krewni byli świadomi działania poza jurysdykcją Kościoła, nic też dziwnego, że nie znalazła tutaj zastosowania zasada supplet Ecclesia.

Episcopo dioecesano habeat, in cuius territorio celebratio matrimonii peragitur, nullamque ab eo potestatem receperit nec umquam probatus sit tamquam veram $\mathrm{ab}$ eo potestatem receperit nec umquam probatus sit tamquam veram potestatem exercens in Ecclesia particulari”. DeC. C. StAnkiewicz 15.12.1992, RRD 84 (1992), s. 669.

84, ,...] sed maxime locum habet simplex ignorantia ex pate fidelium bona fide extra veritatem agentium, potissimum vero ignorantia crassa et supina ex parte presbyteri de existentia facultatis mala fide iudicantis". TAMżE.

${ }_{85}$ Por. J. CARReras, Forma canonica e "favor matrimonii" in una recente sentenzia rotale, Ius Ecclesiae 6 (1994), s. 214.

${ }^{86}$ „Ecclesia supplere nequit facultatem in eo, qui a communione ecclesiali recessit et proprio marte exra communionem hierarchicam cum Episcpo loci celebrationis nuptiarum agere praesumit”. Dec. C. Stankiewicz 15.12.1992, RRD 84 (1992), s. 670. 


\subsection{Wyrok c. Pompedda z 14 lutego 1997 roku}

Przedmiotem sprawy Bracaren. (z archidiecezji Braga w Portugalii) ${ }^{87}$ była domniemana nieważność małżeństwa zawartego 4 kwietnia 1973 roku w sanktuarium maryjnym (położonym na terenie parafii Espinho), pomiędzy Ewą i Filipem, w obecności ks. Henryka, proboszcza parafii Ribeirao. Po nieudanym pożyciu małżeńskim strony wkrótce rozeszły się, otrzymując na wniosek męża separację.

Sprawę o nieważność małżeństwa wniosła do trybunału w Bradze Ewa, podając jako tytuł nieważności niezdolność psychoseksualną męża do podjęcia istotnych obowiązków małżeńskich oraz niemożliwość ustanowienia z nim wspólnoty życia i miłości. Po zawiązaniu sporu (z tytułu niezdolności pozwanego do podjęcia istotnych obowiązków małżeńskich), patron powódki przedstawił nowy tytuł nieważności: niezachowanie formy kanonicznej z powodu braku stosownego uprawnienia u kapłana asystującego przy zawieraniu małżeństwa. Po dodaniu tego nowego tytułu nieważności trybunał przeprowadził instrukcję dowodową (głównie w oparciu o dokumenty), po czym, pomijając tytuł incapacitas, nie stwierdził nieważności małżeństwa $\mathrm{z}$ powodu niezachowania formy kanonicznej ${ }^{88}$.

Po złożeniu apelacji przez powódkę, trybunał apelacyjny, orzekł nieważność związku z tytułu braku formy kanonicznej. Apelacja od tego orzeczenia, złożona przez obrońcę węzła małżeńskiego, sprawiła, że sprawa znalazła się w trzeciej instancji: w Rocie Rzymskiej. Z powodu jednak zaniedbania przez strony czynności procesowych sprawa została umorzona, a po kilku latach została wznowiona. Turnus rotalny c. Pompedda w dniu 14 lutego 1997 roku wydał orzeczenie prawomocne stwierdzające nieważność małżeństwa ob defectum formae.

\footnotetext{
87 Dec. C. Pompedda z 14.02.1997, RRD 89 (1997), s. 103-113.

88 W. GóRALSKI, Problem aplikacji kan. $144 \$ 2$ KPK do dziedziny uprawnienia do asystowania przy zawieraniu małżństwa (na przykładzie wyroku Roty Rzymskiej c. Pompedda z 14.02.1997 r.), w: J. KRAJCZy ński (red.) Podmiotowość osoby ludzkiej i konsens małżeński, Płock 2005, s. 73-75.
} 
Istotnym wątkiem sprawy było to, że rektor wymienionego wyżej sanktuarium, sądząc, że posiada delegację ogólną do błogosławienia małżeństw, delegował innego kapłana do pobłogosławienia małżeństwa Ewy i Filipa. Problem zatem polegał nie tyle na braku delegacji ad casum u kapłana błogosławiącego małżeństwo, ile raczej na braku uprawnienia ogólnego u rektora sanktuarium.

Gdy chodzi o motywy orzeczenia rotalnego, to zostały one ujęte w obszernym wywodzie ponensa ${ }^{89}$, gdzie - poza przytoczeniem generalnych zasad oraz uwag dotyczących formy kanonicznej zawierania małżeństwa (przepisy w tej dziedzinie nie zmieniły się istotowo w stosunku do regulacji KPK z 1917 roku, pod rządami którego zostało zawarte małżeństwo stron) - zwraca baczną uwagę na szereg kwestii szczegółowych dotyczących świadka urzędowego asystującego przy zawieraniu związku.

Wśród stwierdzeń natury ogólnej na uwagę zasługuje podkreślenie roli formy kanonicznej w całokształcie regulacji dotyczących instytucji małżeństwa. Tak więc, odwołując się do orzeczenia c. Stankiewicz z 15 grudnia 1992 roku $^{90}$, ponens zauważa, że wymagana i ustanowiona przez Kościół forma kanoniczna nadaje skuteczność prawną zgodzie małżeńskiej nie tyle $\mathrm{z}$ uwagi na swoją funkcję pragmatyczną i pozytywną w porządku publicznym i społecznym w Kościele, ile raczej ze względu na to, że służy pełniejszemu uznaniu własnego charakteru kościelnego i sakramentalnego, gdyż konsens stanowi centralny i istotny moment znaku sakramentalnego. Nawiązując zaś do Katechizmu Kościoła Katolickiego ${ }^{91}$ redaktor wyroku stwierdza, że duchowny, który asystuje przy zawieraniu małżeństwa, przyjmuje zgodę małżeńską w imieniu Kościoła, a jego obecność, podobnie jak świadków zwykłych, wyraża widzialnie to, że małżeństwo jest rzeczywistością kościelną ${ }^{6}$.

Odnośnie do kwestii szczegółowych myśl Pompeddy koncentruje się wokół tego wszystkiego, co odnosi się do delegowania,

\footnotetext{
89 Por. W. Góralski, Problem aplikacji kan. $144 \$ 2$ KPK..., dz. cyt., s. 76-81.

90 Dec. C. Stankiewicz z 15.12.1992 r., RRD 84 (1992), s. 666.

91 Katechizm Kościoła Katolickiego, Pallotinum 1994, n. 1630.
} 
subdelegowania, ustania i uzupełnienia uprawnienia (uprzednio jurysdykcji) do asystowania przy zawieraniu małżeństwa. Przypomina więc przede wszystkim, iż w doktrynie oraz w orzecznictwie jednoznacznie utrzymuje się, że przepisy dotyczące wymienionych instytucji zawarte w normach ogólnych KPK (tak dawnego, jak i aktualnie obowiązującego) należy aplikować do dziedziny asystowania przy zawieraniu małżeństwa, chyba że na przeszkodzie stoją normy specjalne (kan. 1094-1096 KPK z 1917 roku, a następnie kan. 1108-1109 KPK z 1983 roku), derogujące normy ogólne w takim czy innym punkcie, co w 1952 roku potwierdziła Papieska Komisja do Interpretacji Kodeksu Prawa Kanonicznego, o czym wspomniano wyżej.

Znaczący jest fragment orzeczenia, w którym zwraca się uwagę na to, że uzupełnienie przez Kościół uprawnienia, o którym mowa, dotyczy przypadku błędu powszechnego, nie zaś ignorancji. Ta ostatnia bowiem, będąca zwykłą niewiedzą, pozostaje niejako obojętna w stosunku do jakiegokolwiek poznania, i w konsekwencji sprawia, że ktoś nie przyjmuje jakiegokolwiek sądu o danej rzeczywistości: ani prawdziwego ani fałszywego. Toteż w sytuacji ignorancji i niewiedzy u wiernych, choćby miała ona charakter powszechny, Kościół nie uzupełnia uprawnienia92. Ponieważ ignorancja ma miejsce znacznie częściej niż błąd powszechny, powodowałaby daleko idące rozszerzenie granic uzupełnienia uprawnienia, bardziej niż wymaga tego dobro wspólne ${ }^{93}$.

Gdy chodzi o błąd, stwierdza się w wyroku, to polega on na przyjęciu fałszu za prawdę. Odwołując się do nauczania św. Tomasza z Akwinu ${ }^{94}$, ponens zauważa, że w przypadku błędu ma się do czynienia $z$ aktem, który coś dodaje do ignorancji. Może bowiem istnieć u kogoś ignorancja bez formułowania własnego sądu w sprawach mu nieznanych, i wówczas ma miejsce ignorancja, a nie błąd. Lecz jeśli ktoś wydaje fałszywy sąd w sprawach, których nie zna, po pro-

\footnotetext{
92 Por. Dec. C. Teodori z 11.06.1949, SRRD 41 (1949), s. 289; Dec. C. Huot z 24.05.1973, SRRD 65 (1973), s. 472.

93 DeC. Fiore z 9.02.1962, SRRD 54 (1962), s. 35.

94 Thomas Aquinas, De Malo, q. 3, a. 7.
} 
stu błądzi. Podczas gdy niewiedza jest zwykłym brakiem wiedzy, to ignorancja jest w rzeczywistości niewiedzą tego, co ktoś może i powinien znać; natomiast błąd jest dodaniem twierdzenia fałszu.

Kontynuując swój wywód na temat błędu powszechnego, który różni się istotowo od ignorancji, ponens posługuje się fragmentem własnego orzeczenia z 17 kwietnia 1972 roku $^{95}$. Stwierdza więc, że ilekroć zauważamy, że na skutek błędu powszechnego samo prawo udziela - do poszczególnych aktów - jurysdykcji temu, kto jej nie ma, to czyni to $\mathrm{z} u$ uwagi na dobro wspólne, a więc nie na użytek poszczególnych osób, lecz dla korzyści publicznej. W istocie, racja, która prowadzi do nadania błędowi powszechnemu takich skutków wypływa z konieczności zaradzenia dobru wspólnemu wiernych. Dlatego to Kościół uzupełnia jurysdykcję jedynie dla zaradzenia szkodzie, jakiej doznawałaby społeczność wskutek wielu aktów nieważnych. Aby zatem nastąpiły owe skutki błędu, wymaga się, by zachodziło niebezpieczeństwo powszechnej szkody, nie wystarczy zaś sam błąd ${ }^{96}$.

Za słuszne uważa redaktor wyroku to, co przewija się w doktrynie, a mianowicie pogląd, w myśl którego z błędem w znaczeniu kanonu mamy do czynienia wtedy, gdy ma miejsce fakt publiczny, który per se jest zdolny wprowadzić w błąd nie tę czy inną osobę, lecz każdego bez różnicy. Ów zaś fakt publiczny, który stanowi jakby podstawę konstrukcji prawnej, o której mowa, można stwierdzić i przyjąć jego moc na podstawie splotu okoliczności, byleby i one były publiczne, a więc znane ogółowi obecnych w danym momencie. Gdy zaś tego rodzaju podstawy brak, nie można mówić o błędzie powszechnym wirtualnym, ponieważ dany fakt nie ma mocy wprowadzenia w błąd społeczności.

$\mathrm{W}$ tego rodzaju przypadkach, czytamy następnie w wyroku, nie jest brane pod uwagę mniemanie tych, którzy zwrócili się do duchownego, lecz powszechny sąd wiernych, którzy w danej miejscowości

95 Dec. C. Pompedda z 17.04.1972, SRRD 64 (1972), s. 174.

96 TAMŻE. 
żywią przekonanie, że posługa danego duchownego związana jest z konieczną władzą czy uprawnieniem ${ }^{97}$.

Przytaczając ponownie fragment swego orzeczenia z 17 kwietnia 1972 roku, ponens dotyka z kolei bardzo ważnej kwestii. Stwierdza więc, że nie wymaga się, by błąd powszechny istniał w danym momencie, by faktycznie liczni wierni byli w błędzie; wystarczy błąd powszechny w zasadach swojego działania, inaczej mówiąc, wystarczy, by istniała przyczyna błędu powszechnego, która z natury swojej jest zdolna wprowadzić wiernych w błąd, tak aby wszyscy, wzięci moralnie, w określonych okolicznościach, ulegli mu. Dlatego też błąd nie staje się powszechny w zależności od dużej liczby wiernych obserwujących odpowiednie czynności wykonywane przez duchownego (np. asystowanie przy zawieraniu małżeństwa), lecz błąd, przynajmniej swoją zdolnością, jeśli nie aktem, istnieje wskutek istnienia przyczyny, którą stanowi jakiś fakt publiczny; stąd domniemywa się istnienie błędu, gdy wierni zwracają się do duchownego o dokonanie przezeń jakiegoś prawomocnego aktu. Dokładniej zatem i bardziej właściwie rozwiązywana jest kwestia dotycząca czy to ilości będących w błędzie, czy to jednego czy większej ilości aktów spełnionych w sytuacji błędu powszechnego, problem bowiem należy rozstrzygnąć w oparciu nie o ilość [będących w błędzie czy spełnianych aktów - W.G.], lecz o przyczynę [błędu - W.G.] ${ }^{98}$.

Następnie ponens dotyka kwestii dotyczącej bezpośrednio duchownego asystującego przy zawieraniu małżeństwa. Powołując się na orzecznictwo Roty Rzymskiej stwierdza, że aby uzupełnienie jurysdykcji (uprawnienia) osiągnęło swój skutek, wymaga się, by kapłan lub diakon asystujący przy zawieraniu związku wykonywał w parafii lub w określonym sanktuarium jakiś urząd (funkcje), choćby pomocniczy, co przynajmniej w swym wyrazie zewnętrznym mogłoby zrodzić u wiernych przekonanie o prawomocnym posiadaniu przez niego koniecznego uprawnienia. W przeciwnym wypadku, zaznacza

97 Dec. C. Pompedda z 14.02.1997, RRD 89 (1997), s. 107.

98 Zob. W. Gór ALsKi, Problem aplikacji kan. $144 \$ 2$ KPK..., dz. cyt., s. 79. 
Pompedda, powołując się na doktrynę ${ }^{99}$ i orzecznictwo ${ }^{100}$, bardzo ważne przepisy kodeksowe regulujące władzę zwyczajną i delegowaną stałyby się w praktyce niepotrzebne. Należy zatem uznać, czytamy dalej w wyroku, iż zarówno w świetle dawnych, jak i obowiązujących norm kanonicznych (KPK z 1983 roku) błąd powszechny nie może dotyczyć pojedynczego faktu, lecz powinien dotyczyć podstawy jurysdykcji (uprawnienia), którą suponuje się w odniesieniu do kogoś, gdy tymczasem de facto jej nie posiada. W oparciu o tego rodzaju błąd, jednak powszechny, tak prawny, jak i faktyczny, Kościół uzupełnia brak jurysdykcji (uprawnienia), która w danym przypadku jest ważnie wykonywana, servatis de iure servandis ${ }^{101}$.

W orzeczeniu przypomina się zarazem, iż uzupełnienie jurysdykcji (uprawnienia) dokonuje się także w przypadku wątpliwości pozytywnej i prawdopodobnej, czy to prawnej, czy faktycznej, występującej u duchownego asystującego przy zawieraniu małżeństwa, stosownie do kan. 209 KPK z 1917 r. i kan. $144 \$ 1$ KPK z 1983 roku. Może to mieć miejsce zarówno wówczas, gdy podejmującemu czynności duchownemu trudno jest skonstatować, czy na mocy prawa posiada uprawnienie asystowania przy zawarciu małżeństwa, jak i wtedy, gdy z całą pewnością nie może stwierdzić, czy w konkretnym przypadku weryfikuje się fakt, od którego zależy ważne wykonywanie wspomnianego uprawnienia ${ }^{102}$.

99 G. Michiels, De potestate ordinaria et delegata, Romae 1964, s. 344; E. Regatillo, Institutiones luris Canonici, Santander 1961, s. 284.

100 Dec. c. Heard z 09.12.1953, SRRD 45 (1953), s. 755; Dec. c. Brennan z 29.01.1959, SRRD 51 (1959), s. 41.

101 „Hisce relatis igitur cuique patet ad mentem sive veteris sive novae novae normae canonicae errorem cummunem non posse spectare factum singulare, sed respicere debet fundamentum iurisdictionis, quae supponitur in aliquo, cum de faso desit. Ex illo errore, quidcm communi, sive de facto sive de iure, suppletur ab Ecclesia iurisdictio: quae igitur in singulo casu valide exercetur, servatis servandis". DEc. C. Pompedda z 14.02.1997, RRD 89 (1997), s. 108; W. GóRalski, Problem aplikacji kan. $144 \$ 2$ KPK..., dz. cyt., s. 80.

102 Dec. C. Pompedda z 14.02.1997, RRD 89 (1997), s. 108. 
W części In facto orzeczenia ponens wykazał, że subiektywne przekonanie rektora sanktuarium o tym, że posiada uprawnienie ogólne do błogosławienia małżeństw sprawiło, że - jak sam zeznał - udzielił ks. Henrykowi Ferreira de Faria delegacji osobiście: ustnie i wyraźnie (podobnych delegacji udzielił zresztą wielu innym kapłanom). Nie posiadał on jednak nigdy żadnej delegacji ogólnej do asystowania przy zawieraniu małżeństw zawieranych w sanktuarium.

W odniesieniu do błędu powszechnego wiernych oraz wątpliwości pozytywnej i prawdopodobnej ponens stwierdził, że asystujący przy zawieraniu małżeństwa kapłan nie przejawiał wahań czy wątpliwości, jak to sam zaznaczył w swoich zeznaniach. Jako proboszcz bowiem nie myślał nawet o takiej możliwości (braku uprawnienia) przed przyjęciem zgody małżeńskiej nupturientów. W orzeczeniu podkreślono, że w żaden sposób nie weryfikuje się w tym przypadku błąd powszechny, gdyż zabrakło określonego i stwierdzonego faktu zdolnego per se do wprowadzenia w błąd społeczności wiernych obecnych w sanktuarium. Tak więc kapłan błogosławiący związek małżeński już od lat nie pełnił funkcji kapelana w sanktuarium, będąc proboszczem parafii Ribeirao, odrębnej od parafii Espinho, na której terytorium znajduje się sanktuarium. Pozbawiony mocy jest także argument $\mathrm{z}$ tytułu funkcji proboszcza, a to $\mathrm{z}$ uwagi na zasadę terytoriałności dotyczącą jego władzy. Jeśli zaś wierni zasady tej nie znali, to miała miejsce ich ignorancja, nie zaś błąd. Niezdolny jest też do stworzenia podstawy dla zaistnienia błędu powszechnego fakt powierzenia rektorowi sanktuarium, gdyż wierni nie wiedzą, że stojący na czele tego miejsca świętego winien posiadać delegację ogólną, którą mógłby subdelegować; tu również więc mogła mieć miejsce ignorancja, a nie błąd. Natomiast ci, którzy powinni znać wymogi do ważnej asystencji przy zawieraniu małżeństwa, a więc kapłan asystujący i rektor sanktuarium, nie byli w błędzie, lecz pominęli właściwą ocenę dotyczącą owych wymogów (czy były spełnione) ${ }^{103}$.

Trafna jest konstatacja Pompeddy, iż błąd partykularny (niewielkiej liczby osób) nie może uchodzić za błąd powszechny, i jeśli

103 TAMŻE, s. 111-112. 
uzupełnienie uprawnienia w przypadku tego pierwszego błędu miałoby służyć dobru publicznemu, to nastapiłoby zburzenie całego porządku prawnego w tym obszarze ${ }^{104}$.

Wyrok c. Pompedda, potwierdzający, że uzupełnienie uprawnienia zostało przewidziane jako instytucja chroniąca dobro publiczne Kościoła, i stanowiący wyraz restrykcyjnej tendencji panującej w orzecznictwie rotalnym, może skłaniać do postawienia pytania: czy przysługujące wszystkim wiernym prawa oraz zasada favor $\mathrm{nm}$ trimonii nie wymagałyby przyjęcia nieco szerszej wykładni kan. 144 $\$ 2 \mathrm{KPK}$, aplikowanego do kan. $1111 \S 1 \mathrm{KPK} ?^{105}$

\subsection{Wyrok c. Pinto z 5 lipca 2003 roku}

Orzeczenie w sprawie Romana. z 5 lipca 2002 roku $^{106}$ dotyczy małżeństwa Lukrecji i Leonarda, obojga katolików, zawartego 26 czerwca 1985 roku w domu prywatnym w granicach parafii Pierwszych Męczenników Rzymskich w Rzymie. Dwudziestoczteroletni narzeczony i blisko dwudziestopięcioletnia narzeczona, pozostający ze sobą w relacjach intymnych, po samoczynnym poronieniu przez kobietę zdecydowali się zawrzeć małżeństwo. Wspólnota małżeńska, w której zabrakło potomstwa, po siedmiu latach została przerwana, kiedy to strony podjęły separację, dwa lata później usankcjonowaną na forum cywilnym.

W dniu 3 marca 1995 roku, mężczyzna, przekonany o nieważności swojego małżeństwa wniósł sprawę do Trybunału Kościelnego Regionalnego Lacjum przy Wikariacie Miasta z tytułu braku formy kanonicznej, a także - subordinate - z tytułu wykluczenia potomstwa przez pozwaną.

Po przeprowadzeniu instrukcji dowodowej, podczas której przesłuchano świadków i zbadano dokumenty, 25 stycznia 1996 roku zapadł wyrok pozytywny (wydany przez tylko jednego sędziego) z tytułu

\footnotetext{
104 TAMŻE, s. 112-113.

105 W. Gór Alski, Problem aplikacji kan. 144 \$ 2 KPK..., dz. cyt., s. 89.

106 Dec. C. Pinto z 05.07.2002, RRD 94 (2002), s. 409-414.
} 
braku formy. Po złożeniu przez kobietę apelacji do Roty Rzymskiej i ustanowieniu 29 grudnia 1996 roku turnusu orzekającego, stwierdzono nieważność wyroku pierwszej instancji, stosownie do kan. 1610, n. 7 i 1622, n. 1 KPK.

Mając na uwadze wniosek patronki powódki oraz pozytywną opinię turnusu, Dziekan zarządził prowadzenie sprawy przez Rotę w piewszej instancji. W określonej 2 stycznia 1998 roku formule wątpliwości przyjęto brak formy kanonicznej.

W eksplikacji motywów prawnych podjętych przez ponensa przypomniano najpierw o relacji norm KPK z 1917 roku w kwestii formy kanonicznej do norm Kodeksu obowiązującego. Zwrócono jednocześnie uwagę na trudności związane z interpretacją dyspozycji kan. $1117 \mathrm{KPK}$, a także przypomniano dwa domniemania prawne: $\mathrm{z}$ kan. 1060 i $1101 \S 1 \mathrm{KPK}^{107}$.

Ponens porusza następnie kwestię tzw. domniemań sędziowskich (praesumptiones hominis), które sędzia może uwzględniać lub odrzucać. Przytacza tutaj znaczący fragment orzeczenia c. Bonet z 31 października 1961 roku, gdzie wymieniony audytor stwierdza: „Nie można zapominać, że sędzia $\mathrm{z}$ faktu pewnego i określonego, który bezpośrednio wiąże się z tym, co do którego toczy się spór, może stosować domniemanie (por. kan. 1828 KPK [zob. kan. 1586 KPK z 1983 roku]) ma to tym bardziej znaczenie, gdy chodzi o następujący po sobie ciąg faktów, z których można wyprowadzić domniemanie. $\mathrm{Z}$ tego też powodu sędziowie, odnosząc się do podobnego przypadku uznali, że jeśli przez wiele lat w danym rejestrze małżeństw zawsze czyniono wzmiankę o delegacjach szczególnych, czyli pojedynczych do asystowania przy ich zawieraniu, gdy zachodziła tego potrzeba, i nigdy nie było wzmianki o delegacji ogólnej, to słusznie należy przypuszczać, że małżeństwa zawarte wobc kapłanów, którzy nie mieli władzy zwyczajnej asystowania przy ich zawieraniu, zawarte zostały na mocy delegacji ogólnej: dotyczy to przede wszystkim kapłanów,

107 TAMŻE, s. 110-111. 
którzy są wyznaczeni na stałe do danej parafii, i którzy przez kilka lat asystują tam przy zawieraniu licznych związków"108.

Domniemanie prawne, dodaje Pinto, traci swoją moc wobec faktów, które w sądzie niezbicie dowodzą czegoś przeciwnego ${ }^{109}$. Faktami, które mają moc wyłączenia czy to domniemań prawnych czy błędu powszechnego, zważywszy na przytoczony fragment orzeczenia c. Bonet, jest m.in. obecność całkowicie obca ks. X. na terytorium celebracji małżeństwa, który nigdy nie sprawował tam sakramentów ani nie głosił słowa Bożego ani też nie spełniał innych funkcji parafialnych, a przede wszystkim nigdy nie asystował przy zawieraniu małżeństwa, które to funkcje i posługi będą w przypadku przeciwnym podstawą błędu publicznego; faktem takim jest również przypadkowe celebrowanie małżeństwa w miejscu świeckim terytorium parafialnego, co z zasady nie jest dopuszczane przez proboszcza ${ }^{110}$.

Ponens dodaje, że jeśli ks. X. był całkowicie obcy w stosunku do wspomnianego terytorium, to nie może istnieć żadne praesumptio hominis o jego jakiejkolwiek delegacji: tak ogólnej, jak i szczególnej, z zachowaniem w mocy jakiejś delegacji pisemnej lub stosownej wzmianki w rejestrach w miejscowej parafii ${ }^{111}$.

108 „Praetereundum non est Iudicem ex facto certo et determinanto, quod cum eo, de quo controversia est, directe cohaereat, praesumpionem conicere posse (cf. can. 1828; can. 1586 CIC ' 83 ): hoc valet eo magis quo agitur de tractu successivo factorum e quibus praesumptio deducatur. Qua de re Patres, ad casum propius spectantes, tenuerunt si per plures annos in quodam regestro matrimonium mentio semper fiat de delegationibus particularibus, seu singularibus ad assistendum matrimoniis, ubi casus ferat, atque numquam mentio habeatur de delegatione generali, iure merito conici debre matrimonia contracta coram sacerdotibus, qui potestate ordinaria non gaudent ad iisdem assistendum, celebrata fuisse, ex delegatione generali: hoc praesertim si agatur de sacerdote habitualiter alicui paroeciae addicto, qui per plures annos ibidem plurimis matrimoniis assistit”. Dec. C. Bonet z 30.10.1961, SRRD 53 (1961), s. 479; Zob. także J.M. Serrano Ruiz, Ad cann. 1584-1586, w: P.V. Pinto (red.) Commento al Codice di Diritto Canónico, Città del Vaticano 2001, s. 914. 109 Por. kan. 1585 KPK.

110 Dec. C. Pinto z 05.07.2002, RRD 94 (2002), s. 411.

111 TAMŻE. 
Gdy chodzi o formę delegacji, w wyroku przypomniano, że powinna być ona udzielona wyraźnie (expresse), czy to słownie czy na piśmie czy innym równoważnym znakiem, nie zaś milcząco. Absolutnie wyklucza się delegację domniemaną lub interpretatywną, podobnie jak zwykłą tolerancję okazaną w stosunku do asystującego przy zawieraniu małżeństwa, któremu nie zostało udzielone zezwolenie ${ }^{112}$.

Co się tyczy uzupełnienia uprawnienia temu, kto go nie posiada, redaktor orzeczenia rotalnego przywołuje odpowiedź Papieskiej Komisji do Interpretacji KPK z 26 marca 1952 roku $^{113}$, w myśl której instytucja ta służy nie dobru prywatnemu, lecz wyłącznie dobru publicznemu, jak to przypomniano w wyroku c. Pompedda z 17 kwiertnia 1972 roku, gdzie czytamy: „Przez błąd powszechny samo prawo udziela jurysdykcji temu, kto jej nie ma, do poszczególnych aktów, z uwagi na dobro wspólne, czyli nie poszczególnych osób, lecz ze względu na publiczny pożytek. W rzeczywistości, racja, którą zwykło się przytaczać dla powstania błędu powszechnego, pochodzi z konieczności zaradzenia dobru wspólnemu wiernych [...] Nie bierze się natomiast pod uwagę mniemania tych, którzy udają się do duchownego, lecz ocenę wiernych w danym miejscu"114.

Odnosząc się do kan. $144 \$ 1 \mathrm{KPK}$ ponens widzi tutaj zasadę ogólną dotyczacą wykonawczej władzy rządzenia, której brak uzupełnia Kościół w przypadku błędu powszechnego, tak faktycznego, jak i prawnego, a także w przypadku wątpliwości pozytywnej i prawdopodobnej, czy to prawnej czy faktycznej, na forum zarówno zewnętrznym, jak

\footnotetext{
112 Por. Dec. C. Grazioli z 21.07.1938, SRRD 30 (1938), s. 454.

113 Pontificia Commissio Codici Iuris Canonoici Authentice Inter pretando, Responsum diei 16 martii 1952, AAS 55 (1952), s. 417; Por. F. LóPEZ- IllanA, La suplencia de la facultad de asistir al matrimonio..., dz. cyt., s. 132 i 141-142.; P. PELlEgRino, La supplenza Ecclesiae (can. 144 \$ 1, \$ 2), Ius Canonicum 39 (1999), s. 167.

114 „Per errorem communem ius ipsum iurisdictionem ei qui caret confert, ad singulos actus utique propter bonum commune, seu non singulorum sed publicae utilitatis causa. Sane, ratio quae solet adduci ad errorem communem constituendum, depromitur ex necessitate providendi fidelium bono communi [...] Non considaratur attamen existimatio eorum qui ministrum adierunt, sed existimatio fidelium in loco”. Dec. C. Pompedda z 17.04.1971, SRRD 64 (1971), s. 174.
} 
i wewnętrznym. Nie ma wątpliwości, że zestawiajac kan. $144 \$ 2$ i 1111 $\$ 1 \mathrm{KPK}$, tego rodzaju uzupełnienie władzy może być aplikowane również do małżeństwa. Doktryna uczy, że uzupełnienie władzy rządzenia nie odnosi się do samego działającego, lecz ma tu miejsce zastąpienie braku jurysdykcji działającego przez jurysdykcję nadzwyczajną delegowaną przez prawo, a udzieloną przejściowo przez Kościół działającemu w samym akcie jurysdykcyjnym ${ }^{115}$.

Przechodząc do motywów faktycznych, ponens stwierdza, że kapłan X., który lekkomyślnie asystował przy zawieraniu małżeństwa stron, nie był nowo wyświęconym księdzem czy mało doświadczonym, który pełnił funkcję proboszcza w podrzymskiej diecezji Portuensi et Sanctae Rufinae; prawdopodobnie uległ wyszukanym prośbom przyjaciół. Wiadomo na pewno, że kapłan ten nie był proboszczem ani wikariuszem parafialnym w diecezji rzymskiej; kwestią jest natomiast ustalenie, czy została mu udzielona delegacja do asystowania przy zawarciu owego małżeństwa: czy to ogólna czy szczególna, a także czy zaistniał błąd powszechny.

Przede wszystkim, kontynuuje Pinto, z oczywistością należy wykluczyć, iż miał miejse błąd powszechny co do asystencji prezbitera przy zawieraniu małżeństwa. Przeciwnie, miał miejsce błąd zwykły, nie zaś powszechny. Ks. X. nie był bowiem duchownym, którego parafianie zwykli w tym miejcu prosić o celebrację małżeństwa. Tymczasem chodzi po prostu o kapłana, który jest uważany za prawowicie delegowanego do asystencji przy zawieraniu określonego małżeństwa.

Jak zauważa ponens, w rozpoznawanym przypadku jedyną poważną kwestią było nadużycie ze strony ks. X., iż obawiał się prosić o delegację Wikariat Miasta albo proboszcza wspomnianej wyżej parafii Świętych Męczenników, w granicach której znajduje się oratorium owego prywatnego domu, w którym zostało zawarte małżeństwo. Miał świadomość, że takiej delegacji na pewno nie otrzyma, zważywszy, że diecezja rzymska jest przeciwna praktykom błogosławienia małżeństw w kaplicach całkowicie prywatnych ${ }^{116}$.

115 Zob. G. Michiels, De potestate ordinaria et delegata..., dz. cyt., s. 285.

116 Dec. C. Pinto z 05.07.2002, RRD 94 (2002), s. 412-413. 
Redaktor wyroku następnie podkreśla, iż nikt nie może wątpić, że kapłan X. nie miał delegacji, co okazało się już na początku procesu. Same jego słowa wypowiedziane podczas zeznania, jeśli z jednej strony są znakiem złej wiary samego prezbitera (w jaki sposób bowiem można mu wierzyć, że zupełnie nie zna podstawowych elementów swojej posługi?), to z drugiej zaś strony świadczą, że brakowało zupełnie delegacji do ważnej celebracji małżeństwa.

O złej wierze kapłana świadczy to, co powiedział sędziemu. Wyznał mianowicie, iż pamięta, że został wezwany przez właściciela kaplicy do celebracji małżeństwa, i że mu powiedziano, iż „,wszystko jest w porządku”. Ta sama osoba, do której dotarł, sprawiła, że mógł przynieść rejestr, do którego wpisał małżeństwo; rejestr ten należał do parafii, której był proboszczem w suburbikarnej diecezji Portuensi et Sanctae Rufinae. Dodał nie otrzymał żadnego dokumentu z delegacją lub innego, i w ten sposób w akcie ślubu nie pojawiła się żadna wzmianka o delegacji.

Komentując te słowa, ponens konstatuje, że jeśli ignorancja wymawia właściciela kaplicy, to z pewnością nie wymawia prezbitera, który został upomniany, by nigdy nie odważył się powtórzyć takiego wykroczenia, gdyż działając jako pełniący posługę może odpowiadać również karnie, poza przestępstwem fałszu (kan. 1391, b. 3 KPK), popełnił bowiem przestępstwa, o których w kan. 1384 i $1389 \mathrm{KPK}^{117}$.

Jak się okazało, również właściciel kaplicy doskonale wiedział, że proboszcz parafii Pierwszych Męczenników (na terenie której znajduje się kaplica), nieżyjący już w okresie procesu, był całkowicie i zdecydowanie przeciwny celebracji małżeństwa w tym prywatnym domu, i bardzo słusznie, wszak liturgia, z wielką obawą Kościoła, nie powinna być mieszana $z$ handlem. To współdziałanie między właścicielami owego miejsca i ks. X. co do niegodziwości celebrowania tam małżeństw ujawniają relacje samych stron. Pozwana zeznała bowiem, że wybór kapłana, który ich zaślubił, został dokonany przez właścicieli willi. Fakt celebracji małżeństwa w prywatnej kaplicy znajdującej się na terenie rzymskiej parafii potwierdzily zarówno strony, jak

117 TAMŻE, s. 413. 
i świadkowie w sprawie. Już samo formalne wpisanie małżeństwa do rejestru parafii innego miejsca, zaznacza ponens, jest jakimś pewnym znakiem braku delegacji (wpisu tego brak w rejestrze parafii Pierwszych Męczenników, na terenie której celebrowano małżeństwo); brak tam również jakiejkolwiek adnotacji o tym fakcie. Potwierdził to $\mathrm{w}$ instancji rotalnej aktualny proboszcz tej parafii.

Biorąc pod uwagę, że w rozpoznanej sprawie nie może być mowy o uzupełnieniu uprawnienia kapłana przez Kościół stosownie do kan. 144 KPK, i gdy zdecydowanie nie chodzi o błąd powszechny ani o wątpliwość pozytywną i prawdopodobną, lecz - przeciwnie - o zwykły błąd niepowszechny, ponieważ miejsce celebracji było prywatne, audytorzy turnusu, konkluduje ponens, uzyskali pewność moralną co do nieważności małżeństwa ${ }^{118}$.

Sentencja: „Affirmative, seu constare de matrimonii nullitate, in casu, ob defectum formae" kończy orzeczenie ${ }^{119}$.

Wyrok c. Pinto stanowi instruujący przykład, który wskazuje, iż aplikowanie normy o uzupełnieniu uprawnienia do asystowania przy zawarciu małżeństwa wymaga rzetelnego poznania danej sytuacji. Okazało się, że kapłan, świadom braku delegacji, błogosławił małżeństwo w złej wierze. O błędzie powszechnym nie mogo być tutaj mowy, miał natomiast miejsce błąd zwykły, spowodowany nagannym postępowaniem duchownego.

\subsection{Wyrok c. McKay z 27 października 2006 roku}

Wyrok turnusu rotalnego c. McKay dotyczy sprawy z diecezji Cleveland (U.S.A.) o nieważność małżeństwa z tytułu braku formy kanonicznej. Związek ten strony zawarły 16 lipca 1974 roku $^{120}$, a o pobłogosławienie go strony poprosiły arcybiskupa diecezji Cincinnati (U.S.A.), zaprzyjaźnionego z rodziną nupturienta. Przy zawieraniu małżeństwa nie był obecny miejscowy proboszcz, który musiał wy-

\footnotetext{
118 TAMŻE.

119 TAMŻE.

120 Dec. C. McKay z 27.10.2006, RRD98 (2006), s. 327-333.
} 
jechać, powierzając zajęcie się gościem wikariuszowi. Kapłan ten uprzejmie przyjął hierarchę-celebransa, absolutnie jednak wykluczył udzielenie mu uprawnienia do asystowania przy zawarciu małżeństwa. Czymś dziwnym określa ponens brak kurtuazji proboszcza, który nie podjął w swojej parafii mającego tam przybyć arcybiskupa, metropolity tamtejszej prowincji kościelnej.

$\mathrm{Na}$ taki stan rzeczy pewne światło rzuca fakt, że powód w sprawie był bratankiem owego arcybiskupa, który jako celebransa ceremonii ślubnej zaproponował swojego biskupa pomocniczego; niewątpliwie wszystko zostało bezpośrednio uzgodnione między arcybiskupem i rodziną powoda, a następnie jedynie przekazane przez narzeczoną własnemu proboszczowi.

Stosownie do kan. $1103 \$ 2$ i $470 \$ 2$ KPK z 1917 roku, w księgach parafialnych ochrzczonych fakt zawarcia małżeństwa został należycie odnotowany własnoręcznie przez proboszcza, jakkolwiek z pominięciem wzmianki o upoważnieniu, którego wymagał biskup sprawujący obrzęd. Posłuszny tym normom proboszcz przesłał do proboszcza parafii miejsca chrztu mężczyzny powiadomienie o zawarciu małżeństwa, którego to powiadomienia egzemplarz znalazł się w aktach sprawy ${ }^{121}$.

Wspólnota małżeńska nie zawsze była zgodnie prowadzona, a gdy kobieta w marcu 1993 roku otrzymała wiadomości o trwających nadużyciach ekonomicznych męża, jak jasno stwierdza sam powód, oburzona tym, bezzwłocznie zerwała życie małżeńskie. Mężczyzna w międzyczasie zawarł związek z inną kobietą, a nastepnie kilkakrotnie wnosił sprawę o stwierdzenie nieważności małżeństwa. Jedna $\mathrm{z}$ nich, $\mathrm{z}$ tytułu braku formy kanonicznej, została wniesiona na forum Trybunału w Cleveland i została rozstrzygnięta pro nullitate. Apelacja skierowana bezpośrednio do Roty Rzymskiej została odesłana do postępowania w trybie zwyczajnym, które zakończyło się wyrokiem negatywnym wydanym 23 listopada 2000 roku przez turnus c. Monier. Po ponownym złożeniu przez powoda apelacji został ustanowiony nowy turnus rotalny, który rozpoznał sprawę

121 TAMŻE, s. 327-328. 
w trzeciej instancji. Po przyjęciu pism obrończych i uwag obrońcy węzła małżeńskiego 27 października 2006 roku turnus wydał wyrok pro vinculo ${ }^{122}$.

W motywach prawnych orzeczenia zaznaczono, że małżeństwo zawarte 16 lipca 1974 roku w kościele parafialnym św. Bonifacego w Cleveland obowiązywało niewątpliwie prawo zawarte w Kodeksie Pio-Benedyktyńskim, w kan. 1094-1103.

W szczególności, stwierdza redaktor orzeczenia, aby strona katolicka mogła ważnie zawrzeć małżeństwo, powinna wyrazić konsens małżeński wobec ordynariusza miejsca albo proboszcza albo kapłana delegowanego przez jednego z nich oraz przynajmniej dwóch świadków. Każdy więc kapłan, nawet posunięty w godności kościelnej, choćby nawet kardynał albo biskup, nie może asystować przy zawieraniu małżeństwa, chyba że czyni to $\mathrm{z}$ racji urzędu (ordynariusza miejsca lub proboszcza) albo delegacji.

Poza tym przypomniano w wyroku, że kan. $1096 \$ 1$ KPK wymaga, by upoważnienie do asystowania przy zawarciu małżeństwa udzielane przez tego, kto posiada taką władzę w tej dziedzinie, było udzielane kapłanowi określonemu do określonego małżeństwa, a ponadto by delegacja była wyraźna (delegatio expressa). Podkreślono również, że dyscyplina kodeksowa podawała dokładne normy, nieco surowe, lecz praktyka łagodziła je, szczególnie po autentycznej interpetacji z 26 marca 1952 roku, która przyjmowała, że niewątpliwie asystencja małżeńska jest równoważna $\mathrm{z}$ aktem jurysdykcji. Bezpiecznie więc do przypadku delegacji do asystowania przy zawarciu małżeństwa można aplikować normy kodeksowe o delegowaniu władzy jurysdykcyjnej, nie wykluczając, stosownie do kan. 209 KPK, uzupełnienia jurysdykcji mocą błędu powszechnego ${ }^{123}$.

Znamienne jest wyjaśnienie w wyroku zwrotu kan. $1096 \$ 1$ KPK licentia expressa dotyczącego delegacji. Otóż ponens zauważa, że należy przyjąć, iż akt, przez który udziela się kapłanowi upoważnienia do asystowania przy zawarciu małżeństwa, najpierw rodzi się

\footnotetext{
122 TAMżE, s. 328-329 i 333.

123 TAMŻE, s. 329.
} 
„wewnątrz” (w intencji delegującego), a następnie zostaje ujawniony na zewnątrz. Z tej samej więc racji najpierw należy rozważyć intencję delegującego, a następnie sposób, poprzez który została ona ujawniona, czyli wyrażona ${ }^{124}$.

Tak prawo, jak i praktyka kanoniczna, stwierdza ponens, nie przepisują sposobu udzielenia delegacji, tak by była ważna, choć preferują formę pisemną, $\mathrm{z}$ braku bowiem autentycznego dokumentu może powstać - na forum zewnętrznym - wątpliwość, czy delegacja została rzeczywiście udzielona. Stosownie zaś do kan. $200 \$ 2$ KPK z 1917 roku, „na tym, kto twierdzi, że jest delegowany, ciąży obowiązek udowodnienia delegacji"125.

Wyjaśniając znaczenie delegacji, czytamy w orzeczeniu, doktryna i orzecznictwo potwierdzają, że z całą pewnością nie wystarczy delegacja milcząca lub domniemana albo interpretatywna, kto bowiem milczy, w ogóle delegacji nie wyraża; kto zaś tak wątpliwie wypowiada się, że wymaga to interpretacji albo domniemania, jego wolę należy uznać za wyrażoną nieskutecznie, ponieważ w rzeczywistości nie można jej stwierdzić. Dlatego np. zwykła tolerancja kompetentnej władzy albo jej nieuwaga nie może przemawiać za faktem celebracji ślubu przez kapłana pozbawionego delegacji, delegowanie bowiem jest aktem, przez który delegujący rozumnie udziela komuś uprawnienia do asystowania przy zawarciu małżeństwa, wyrażając w jakiś sposób własną intencję ${ }^{126}$.

Jednak prawo, dodaje McKay, nie przepisuje określonej formy słów, porzez którą udzielana jest delegacja, ani też nie neguje możliwości zezwolenia na asystencję formułą przynajmniej równorzędną, nawet powzietą implicite. Bardzo dobrze więc czyni proboszcz, który używa formy pisemnej, iż kapłanowi X. udziela uprawnienia do asystowania

\footnotetext{
124 „Attenta quaestione delegationis, verbum faciendum est de sensu locutionis licentia expressa. Actus igitur quo sacerdoti conceditur licentia adsistendi nuptiis primo delegantis intus oritur at dein foras manifestari debet. Pari ergo ratione primo consideranda est intentio delegantis dein forma quacum manifestanta seu expressa est eadem". TAMŻE.

125 TAMŻE.

126 TAMŻE, s. 330.
} 
przy zawieraniu małżeństwa Tytusa i Kai, i nikt nie może wówczas wątpić o intencji wyrażonej w taki sposób. Jednak stosownie do prawa wystarczy, że proboszcz przynajmniej deklaruje temuż kapłanowi, że w swojej miejscowości zezwala mu asystować przy zawieraniu małżeństwa tychże narzeczonych, choć działa nieroztropnie, jeśli wśród dokumentów dochodzenia przedślubnego pomija adnotację udzielonego zezwolenia. Tymczasem nie można jednak wątpić o intencji i woli proboszcza ${ }^{127}$.

Wyraźne zezwolenie na asystowanie przy zawarciu małżeństwa, kontynuuje audytor rotalny, może być udzielone również znakami danymi implicite. Przede wszystkim prawo nie wymaga od delegującego, by delegacja była udzielona bezpośrednio i by bezpośrednio była zaakceptowana przez delegowanego. Wystarczy bowiem, by ktoś prosił kompetentną władzę o udzielenie uprawnienia asystencji małżeńskiej określonemu kapłanowi do określonego małżeństwa. Jeśli więc w danym przypadku narzeczeni lub ich krewni zajmujący się sprawą proszą proboszcza, aby kapłan X. mógł przewodniczyć ceremonii ślubnej, z pewnością wystarczy pozytywna odpowiedź proboszcza; z tej samej racji wystarczy również pozytywna odpowiedź kapłana X. udzielona zapraszającym narzeczonym lub ich krewnym, którzy komunikują mu zgodę proboszcza, by stosownie do normy prawa uważał się za posiadającego uprawnienie do celebrowania ślubu.

Z tej samej racji wystarczy przyjęcie delegacji dokonane pośrednio (indirecte), prawo nie wymaga bowiem, by delegowany wyraził akceptację bezpośrednio delegującemu ${ }^{128}$.

Gdy chodzi o sferę dowodzenia, ponens przyjmuje, że udowodnienie braku faktu koniecznie różni się od udowodnienia faktu pozytywnego: np. nie ma dokumentu nie-chrztu, ponieważ nikt z racji urzędu nie może autorytatywnie zdeklarować, że dany fakt absolutnie nie miał miejsca. Dowodzenie więc pominięcia czegoś, np. chrztu może się dokonać jedynie na drodze pośredniej i prawdopodobnej. Podobnie jest w rozpoznawanym przypadku: w osądzeniu

\footnotetext{
127 TAMŻE.

128 TAMŻE.
} 
o domniemanym pominięciu delegacji należy postępować poprzez wskazówki i poszlaki, domniemania prawne i faktyczne, przechodząc logicznie od faktów pewnych do prawdopodobnego przypuszczenia o czymś niepewnym ${ }^{129}$.

Dotykając z kolei kwestii błędu powszechnego (kan. 209 KPK), w przypadku którego następuje uzupełnienie władzy asystowania przy zawieraniu małżeństwa, ponens podkreśla, że błąd jest sądem fałszywym, błądzący więc korzystając z władzy intelektywnej w osądzaniu całkowicie zaprzecza rzeczywistości. Przedstawiciele doktryny słusznie odróżniają błąd od ignorancji lub wątpliwości, które są stanem ducha w stosunku do rzeczywistości, trwającym przed dojściem do powzięcia sądu. Należy jednak zwrócić uwagę na dokładne znaczenie błędu powszechnego w przypadku celebracji małżeństwa wobec kapłana pozbawionego urzędu albo delegacji. Przede wszystkim trzeba przyjąć opinię, w myśl której błąd wirtualnie powszechny zachodzi nawet wtedy, gdy większa część danej społeczności nie popada aktualnie w błąd. Mówiąc inaczej, error communis w rozumieniu kan. $209 \mathrm{KPK}$ z 1917 roku niewątpliwie ma miejsce wtedy, gdy istnieją takie okoliczności przypadku, iż gdyby społeczność przyjęła wiadomość o braku upoważnienia u kapłana, popadłaby w błąd ${ }^{130}$.

Należy jednak pamiętać, zauważa McMay, iż błąd powodujący uzupełnienie władzy powinien dotyczyć braku delegacji. Kwestię bowiem odnoszacą się do uzupełnienia władzy można brać pod uwagę jedynie wówczas, gdy wspólnota w jakiś sposób znała konieczność jakiegoś zezwolenia. Błąd więc rodzi się wówczas, gdy okoliczności szczególnego przypadku skłaniają wspólnotę do tego, by fałszywie sądziła, iż kapłan uzyskał zezwolenie od kompetentnej władzy. Lecz tam, gdzie wspólnota generalnie ignoruje znaczenie prawa o formie kanonicznej małżeństwa, z trudnością można zrozumieć błąd

\footnotetext{
129 TAMżE, s. 330-331.

130 „Alias verbis, error communis sensu can. 209 CIC 1917 secure habetur ubi talia sunt adiuncta casus, ut si nototias eorum accipiat communitas, in errorem deducatur". ТАмżE, s. 331.
} 
w tej sprawie, ponieważ nikt nie ma wówczas motywu do powzięcia fałszywego sądu o tym, że kapłanowi zostało udzielone zezwolenie do asystencji małżeńskiej: ignorowanie bowiem rzeczy nie jest tym samym, co błądzenie w tej samej sprawie. Błąd więc, który uzupełnia władzę asystowania przy zawieraniu małżeństwa jest jedynie błędem faktycznym (error facti). W rozpoznawanym przypadku wykluczony jest całkowicie błąd prawny, nikt bowiem nie relacjonuje, czy wspólnota fałszywie mniemała (lub nie), że nie wymaga się w ogóle zezwolenia na asystencję, albo że wszyscy kapłani ipso facto są w taką władzę wyposażeni, i to wszędzie. Kwestia całkowicie inna, na którą należy zwrócić uwagę w rozpoznawanym przypadku, dotyczy tego, czy wspólnota mniemała (lub nie), iż celebrans jest wyposażony w konieczną władzę, czy to zwyczajną czy delegowaną ${ }^{131}$.

Ponadto, przypomniano w orzeczeniu, obowiązujące dwie reguły: 1) ciężar dowodzenia spoczywa na tym, kto coś twierdzi (kan. 1748 $\$ 1$ KPK z 1917 roku i $1526 \$ 1$ KPK z 1983 roku; 2) małżeństwo cieszy się przychylnością prawa (kan. 1014 KPK z 1917 roku i kan. 1060 KPK z 1983 roku) ${ }^{132}$.

W części In facto orzeczenia ponens stwierdza na wstępie, iż w rzeczywistości do rozważenia są dwie kwestie, które powinny być potraktowane w sposób przyporządkowany: 1) czy udzielenie zezwolenia na asystowanie przy zawarciu małżeństwa zostało właściwie udzielone biskupowi (wówczas arcybiskupowi Cincinnati); 2) jeśli zaś nie, to czy w rozpoznawanym przypadku wymienionemu hierarsze została uzupełniona władza w sytuacji będu powszechnego ${ }^{133}$.

Gdy chodzi o kwestię pierwszą, redaktor wyroku stwierdza, że odpowiedź może być tylko pozytywna. Liczne bowiem okoliczności analizowanego przypadku jasno prowadzą do wykluczenia tego, iż miało miejce pominięcie wymaganego zezwolenia. Tak więc powód w swoich zeznaniach wyraźnie przyjmuje, iż wszystko, co dotyczyło przygotowania do małżeństwa, zlecił pozwanej. Zeznał, iż powierzył

\footnotetext{
131 TAMŻE.

132 TAMŻE.

133 TAMŻE.
} 
jej przygotowanie do ślubu, a sam nie miał żadnych kontaktów z proboszczem (parafii św. Bonifacego), poza wstępnym spotkaniem. Pozwana zaś, wychodząc bardzo chętnie naprzeciw pragnieniom rodziny narzeczonego, zaangażowała własnego proboszcza i prosiła go, by do celebrowania obrzędu zaślubin imiennie został zaproszony arcybiskup archidiecezji Cincinnati. Wynika z tego, że kobieta wiedziała, choć może niezdolna była do posługiwania się określonymi terminami kanonicznymi, że w sprawie tej powinno wymagać się zezwolenia proboszcza; wynika jednocześnie i to, że proboszcz takiego zezwolenia chętnie udzielił, powierzając jednocześnie wikariuszowi parafialnemu przygotowanie nadchodzącej celebracji. W tej sprawie pozwana zeznała, iż pamięta spotkanie, w którym proboszcz wyraził obiekcję, czy jest czymś właściwym prosić arcybiskupa, by przewodniczył cremonii ślubnej. Pytany, czy zaakceptowałby, by ceremonii zawarcia małżeństwa przewodniczył arcybiskup, odpowiedział, że tak $^{134}$. Jednocześnie pewne jest, że krewni mężczyzny zaprosili arcybiskupa nie bez wiedzy proboszcza, lecz raczej wyrażającego na to jednoznacznie zgodę. Poza tym, w świetle akt proboszcz prezentuje się jako dokładny administrator, znający prawo odnoszące się do spraw duszpasterskich. Ciężko już chorując, znakami i pisemnie zeznał na temat swojej praktyki pastoralnej w kwestiach małżeńskich: „Zazwyczaj ja dokonuję przygotowania (do małżeństwa), chyba że dokumentacja została przygotowana przez innego kapłana"135. A dawny jego wikariusz parafialny zeznał: „Moje założenie było takie, iż proboszcz parafii św. Bonifacego, który zajmował się przygotowaniem tego ślubu, zatroszczył się również o wszystkie pozostałe sprawy"136.

134 „All I remember is meeting with the priest to say, «Is it okay to bring Archbishop B. in to presideover the cermony?» [...] he was fine with that [...] I distinctly recall asking the Pastor of st. Boniface' «if would be acceptable for the Archbishop to celebrate our wedding» and he responded that it would be". TAMżE, s. 332 .

135 "Ordinarily I would do the preparation unless it was documented by another priest”. TAMŻE.

136 „My presumption would have been that Fr.L. [parochus S. Bonifacii], who took, care of the preparations for this particular wedding, would have taken care of all these things". TAMŻE. 
Trudno więc sobie wyobrazić, by taki proboszcz nie odpowiedział pozytywnie na prośbę pozwanej, nie udzielając jednocześnie wymaganego zezwolenia. Każdy bowiem proboszcz wie, że w granicach swojego terytorium parafialnego ma prawo błogosławić małżeństwa wraz $\mathrm{z}$ władzą udzielania innym zezwolenia ${ }^{137}$.

Przeciw takiej konkluzji, stwierdza McKay, przemawia pominięcie adnotacji na stronie dotyczącej narzeczonej protokołu badania przedślubnego. Na obiekcję tę ponens odpowiada, że po pierwsze, taka adnotacja nie jest wymagna do ważności; poza tym nie wiadomo, w jakim czasie arcybiskup został zaproszony albo kiedy narzeczona uzgadniała sprawę $\mathrm{z}$ proboszczem. Badanie bowiem narzeczonych było przeprowadzone na miesiąc przed ślubem, natomiast wybór celebransa, jeśli w owym czasie nie był jeszcze potwierdzony, to pominięcie nazwiska celebransa łatwo można wyjaśnić: proboszcz więc w tym przypadku przez zwykłą nieuwagę pominął ostatni element formularza, a potem go uzupełnił. Do takiego wniosku skłania także fakt, iż rodzina powoda na początku wahała się co do wyboru celebransa; pozwana zeznała, iż uprzednio między członkami rodziny pozwanego mówiło się o celebransie w osobie kardynała-arcybiskupa Filadelfii Łacinników, albo arcybiskupa Cincinnati. Wzmocnienie tego wniosku ponownie znajduje swoje miejsce w dokonanym powiadomieniu proboszcza chrztu powoda, by stosownie do normy prawa odnotował fakt zawarcia małżeństwa w księdze ochrzczonych ${ }^{138}$.

Egzemplarz dokumentu, czytamy w wyroku, znajduje się w aktach sprawy pierwszej instancji, a jako świadek urzędowy jest wskazany (pismem odręcznym) arcybiskup. W formularzu drukowanym figuruje określenie celebransa: „Pastor” albo „Delegate”. Jednak przy obu rubrykach umieszczono linię, która nie wykreśla tych słów ani nie uniemożliwia ich odczytania. Natomiast wyraz „Delegate” został ręcznie zakreślony.

Prawdopodobnie, przyjmuje redaktor orzeczenia, formularz został wypełniony w sposób niemal automatyczny: w myśl tego, co

\footnotetext{
137 TAMŻE.

138 TAMŻE, s. 332-333.
} 
zazwyczaj ma miejsce, skreślony jest napis „Delegate”, a następnie, po odkryciu błędu skreślono również wyraz „Pastor”. Wreszcie, by zapobiec u czytelnika dwuznaczności, piszący usiłował naprawić brak i oznaczył kółkiem „Delegate”. Jest to zatem inny argument przemawiający za prawidłowo udzielonym i w czasie zawierania małżeństwa publicznie znanym zezwoleniem dla arcybiskupa.

$\mathrm{Z}$ uwagi zatem na prawowicie udzieloną delegację lub przynajmniej z uwagi na nierozwiązalną wątpliwość w sprawie tejże delegacji ważnie udzielonej nie ma potrzeby rozprawiać o możliwym udzieleniu władzy na podstawie błędu powszechnego ${ }^{139}$.

Sentencja wyroku: „Affirmative ad primum, negative ad alterum, seu non constare de matrimonii nullitate" kończy wyrok ${ }^{140}$.

Orzeczenie c. McKay stanowi przykład wnikliwej analizy przypadku, w którym chodziło o stwierdzenie, czy arcybiskup archidiecezji Cincinnati, asystując w charakterze świadka kwalifikowanego przy zawieraniu małżeństwa stron poza własną diecezją, otrzymał od proboszcza miejsca delegację uprawnienia. Zarówno precyzyjny wywód ponensa w przedmiocie delegacji uprawnienia do asystencji małżeńskiej podjęty w części In iure, jak i drobiazgowe wręcz dociekanie nad dotarciem do prawdy o małżeństwie (w tymże aspekcie) zaprezentowane w części In facto zasługują na prawdziwe uznanie.

W wyroku nie wypowiedziano się na temat ewentualnego uzupełnienia uprawnienia do asystencji małżeńskiej ${ }^{141}$.

\section{Zakończenie}

Forma zawarcia małżeństwa kanonicznego, ustanowiona w celu wyeliminowania małżeństw tajnych, stanowi instrument służący prawdzie o małżeństwie. Wymagana przez prawo pozytywne (prawo naturalne wymaga jedynie wymiany między stronami zgody

\footnotetext{
139 TAMŻE, s. 333.

140 TAMŻE.

${ }^{141}$ Por. M.A. Ortíz, La supplenza di facoltà per assistere al matrimonio..., dz. cyt., s. 64 .
} 
małżeńskiej), przesądza o tym, że tytuł nieważności w postaci defecus formae opiera się na normie prawa czysto kościelnego, nie zaś naturalnego ${ }^{142}$. Z drugiej strony uznaje się kompetencję Kościoła do określenia formy „prawowitej” wyrażenia konsensu, na podstawie wymiaru społecznego i kościelno-sakramentalnego małżeństwa, właśnie dlatego, że zgoda małżeńska jest „aktem kościelnym”. Nietrudno było uświadomić sobie, że prawowita forma jest w stanie przekształcić relację prywatną kontrahentów w małżeństwo (jako relację prawną).

W strukturze formy kanonicznej znaczące miejsce należy przypisać świadkowi kwalifikowanemu, inaczej urzędowemu (występuje jako osoba publiczna), który pyta nupturientów o zgodę i przyjmuje ją w imieniu Kościoła. Świadkiem tym mogą być jedynie ordynariusz miejsca i proboszcz (w granicach własnego terytorium) oraz inni kapłani i diakoni, którzy zostali przez nich delegowani (na stałe lub do poszczególnych małżeństw); możliwość delegowania wiernych świeckich (kan. 1112 KPK) stanowi tutaj wyjątek.

Chcąc ograniczyć do maximum nieważność małżeństwa z powodu braków formalnych (niezachowania formy kanonicznej), ustawodawca wprowadził pochodzacą z prawa rzymskiego instytucję uzupełnienia przez Kościół uprawnienia świadka urzędowego do asystowania przy zawieraniu małżeństwa. Znajduje ona swoje zastosowanie w sytuacji błędu powszechnego oraz wątpliwości pozytywnej i prawdopodobnej.

Interpretacja odnośnych norm prawnych przyjęta zarówno przez doktrynę, jak i orzecznictwo rotalne (zaprezentowane w niniejszym opracowaniu na przykładzike kilku wyroków) pozwalała przyjąć, że stosując uzupełnienie braku uprawnienia (podobnie jak braku jurysdykcji), Kościół kieruje się humanizmem, co znamionowało w tym zakresie już prawo rzymskie. Coraz powszechniejsze stawało się przekonanie, że chodzi tutaj o aplikację zasady favor matrimonii, która zajmuje znaczące miejsce w kościelnym systemie małżeńskim ${ }^{143}$.

142 Por. Dec. C. Alwan z 15.02.2007, RRD 99 (2007), s. 6.

143 M.A. ORtíz, La supplenza di facoltà per assistere al matrimonio..., dz. cyt., s. 58. 
Znaczenie i rolę normy prawnej o uzupełnieniu jurysdykcji (uprawnienia) w porządku prawnym Kościoła akcentuje m.in. H. Hermann. Z jednej strony, zauważa wymieniony autor, norma ta dotyczy ważnej sfery samego prawa, z drugiej zaś zawiera i wyraża również inny istotny aspekt: odnosi się do działalności zbawczej Jezusa Chrystusa urzeczywistnianej przez Kościół. W swej celowości, zasada uzupełnienia ukazuje się jako służąca - w sposób szczególny i skuteczny - porządkowi zbawienia, chroniąc wiernych przed utratą czegoś istotnego w ich życiü ${ }^{144}$.

Od samego początku funkcjonowania instytucji uzupełnienia jurysdykcji (uprawnienia) norma ta miała służyć rozwiązywaniu sytuacji, w których - na skutek błędu powszechnego lub wątpliwości pozytywnej i prawdopodobnej - wiernym zagrażało niebezpieczeństwo szkody duchowej ${ }^{145}$. Nie ulegało wątpliwości, że ratio legis owej normy stanowi dobro publiczne, choć jednocześnie nie może determinować konkretnego zastosowania instytucji suppletio iurisdictionis (facultatis) ${ }^{\mathbf{1 4 6}}$. „Jedyną i adekwatną racją, dla której Kościół uzupełnia brak władzy, czytamy w wyroku c. Pinto z 11 grudnia 1972 roku, jest wymóg ochrony dobra wspólnego, czyli unikania zła wspólnego. Nie chodzi zatem o dobro czysto prywatne"147. A zdaniem F. Lópeza-Illany, „,racją uzupełnienia jurysdykcji przez Kościół jest dobro wspólne, które wymaga pewności co do jej wykonywania, na ile dotyczy interesu publicznego, nie zaś czysto prywatnego"148 .

${ }^{144}$ H. Hermann, Relazioni eschatologiche del can. 209, Apollinaris 43 (1970), s. 137-138 i 146.

145 P.C. BARRY, Error communis et delegatio ad matrimonium assistendum, Periodica 48 (1959), s. 209.

146 D. CzUprý́ski, Uzupełnienie upoważnienia do asystowania przy zawieraniu małżeństwa..., dz. cyt., s. 44-45; A. Nita, La suplencia de la facultad de asistir al matrimonio en caso de eror común..., dz. cyt., s. 89.

147 „Unica et adeguata ratio ob quam Ecclesia defectum potestatis supplet est exigentia boni communis promovendi vel mali communis vitandi. Non ergo ob bonum mere privatum”. DEC. C. Pinto z 11.12.1972, SRRD 64 (1972), s. 757.

148 „La razón de esta suplencia de la Iglesia es el bien común, que exige certezza sobre el ejercicio de la jurisdicción en cuanto pueda interesar, no en lo que sea de 
Podobnie twierdzi A. Nita, podkreślając, że zarówno Rota Rzymska, jak i większa część przedstawicieli doktryny ochronę dobra wspólnego uznają za wiodący motyw normy o uzupełnieniu uprawnienia do asystowania przy zawieraniu małżeństwa, choć nie wspomina o tym ustawodawca. Autor ten dodaje, że w sytuacji błędu powszechnego oraz wątpliwości pozytywnej i prawdopodobnej zachodzi potrzeba ochrony owego dobra wiernych ${ }^{149}$.

W związku z kwestią dotyczącą dobra wspólnego jako ratio legis normy o uzupełnieniu uprawnienia do asystencji małżeńskiej ${ }^{150}$ pojawiło się pytanie, o to, czy dobro wspólne chronione jest również w przypadku uzupełnienia delegacji do asystowania przy określonym małżeństwie. Jakkolwiek Papieska Komisja do Interpretacji KPK, w swojej odpowiedzi z 26 marca 1952 roku potwierdziła stosowanie zasady Ecclesia supplet w przypadku delegacji ogólnej, co praktykowano od dawna, to jednak nie potwierdziła ani nie zaprzeczyła, czy sprawa jest aktualna również w przypadku delegacji szczególnej, a więc odnoszącej się do danego małżeństwa (delegatio ad actum). Podczas gdy dla jednych autorów kwestia pozostaje dyskusyjna ${ }^{151}$, to dla większości jest czymś oczywistym, że w sytuacji błędu powszechnego Kościół uzupełnia uprawnienie także w odniesieniu do kapłana, który bez delegacji asystuje przy zawarciu tylko jednego

interés meramente privado”. F. López IllanA, La suplencia de la facultad asistir al matrimonio..., dz. cyt., s. 124.

149 „Tanto la Rota Romana como la mayoría de la doctrina entiende que el bien común, como «ratio legis» de la suplencia, es requisito indispensable para aplicar dicho instituto". A. Nita, La suplencia de la facultad de asistir al matrimonio..., dz. cyt., s. 89.

${ }^{150}$ Niektórzy przedstawiciele doktryny dobro powszechne postrzegali nie jako ratio legis normy prawnej, lecz jako jej cel. Por. E. Regatillo, Ius sacramentarium, Roma 1946, s. 358; J. ReED, Error communis in actu assistendi matrimonio, Periodica 48 (1959), s. 560.

151 Por. Ph. Augirre, An praescriptum can. 209 applicandum sit matrimonio, Periodica 42 (953), s. 162. 
małżeństwa, byleby istniało niebezpieczeństwo szkody ogólnej powstałej z błędnego sądu ${ }^{152}$.

Należy zauważyć, że posoborowa Papieska Komisja do Rewizji KPK, formułując kan. 144 KPK miała na względzie przede wszystkim ochronę instytucji małżeństwa przed ogromną liczbą małżeństw nieważnych, a także wykluczenie wszelkiej wątpliwości co do nieważności małżeństwa z powodu braku formy. Czy wobec tego można uznać, że intencją Komisji było wyłączenie z możliwości uzupełnienia delegacji do określonego małżeństwa? Jak się wydaje, argumenty przemawiające na rzecz uzupełnienia uprawnienia są mocniejsze. Przede wszystkim dlatego, że dobro powszechne, wskazywane jako główny punkt sporny - nie jest warunkiem stawianym przez prawo. Lecz będąc jednak ratio legis normy prawnej, niewątpliwie zostaje osiągnięte niezależnie od liczby przypadków, których dotyczy. A ponadto nie sposób nie zgodzić się z tym, że małżeństwo nie jest sprawą prywatną kontrahentów. Stąd w przypadku braku uzupełnienia delegacji ad actum należałoby mówić również o szkodzie powszechnej.

Dobro powszechne przemawia zatem za przyjęciem opinii, w myśl której uzupełnienie uprawnienia następuje również w przypadku braku delegacji do określonego małżeństwa ${ }^{153}$.

\section{Asupplying the lack of delegation to assist in celebrating marriage as an expression of protection of the common good}

\section{Summary}

Even though marriage arises from the consent of parties (can. $1057 \$ 1$ of the Code of Canon Law), it is necessary to preserve the canonical form (ordinary or extraordinary) for the validity of this relationship.

Assuming that the form of marriage was established in order to eliminate secret marriages, canon $144 \$ 1$ of the current Code of Canon Law states that

\footnotetext{
152 Por. D. Faltin, De sensu et applicatione can. 209 in casu sacerdotis qui, delegatione necessaria careens, matriminio assistit, Appolinaris 36 (1963), s. 67; D. CzUPRYŃski, Uzupełnienie upoważnienia..., dz. cyt., s. 146.

153 D. Czupryński, Uzupetnienie upoważnienia..., dz. cyt., s. 145-147.
} 
in the event of factual or legal common error and in positive and probable doubt of law or of fact, the Church supplies executive power of governance for both the external and internal forum.

Canon $144 \$ 1$ of the same Code, on the other hand, declares that the same provision applies to the powers referred to, e.g. in canon $1111 \S 1$ of the Code of Canon Law. This canon regulates that a local ordinary can delegate (to priests and deacons) of assisting at celebrating marriages.

After discussing the role of a marriage witness and the character of his/ her delegation as well as the development of legal form of supplying this delegation, the author takes up the issue of supplying this delegation in an event of common error or positive and probable doubt of law or fact in historical context, and then provides examples of supplying the delegation to assist in marriage in sentences of the Tribunal of the Roman Rota (from years 1992-2006), including a precedent-setting sentence in the case of Stankiewicz of 15 December 1992.

In conclusion, attention was paid to the ratio legis of the legal norm on supplying the delegation, which is bonum commune.

Słowa kluczowe: małżeństwo, asystowanie przy zawarciu małżeństwa, uzupełnienie uprawnienia do asystowania przy zawarciu małżeństwa, dobro wspólne

Key words: marriage, assisting in marriage, supplying the right to assist in marriage, common good

\section{Nota o autorze}

Ks. prof. dr hab. Wojciech Góralski - założyciel i pierwszy redaktor naczelny kwartalnika „Ius Matrimoniale”, wicprzewodniczący Stowarzyszenia Kanonistów Polskich, sędzia w Sądzie Biskupim w Płocku. 